by Dominique Cluzel $^{1}$, Pierre Maurizot ${ }^{1,2}$, Julien Collot ${ }^{1,3}$ and Brice Sevin ${ }^{1,3}$

\title{
An outline of the Geology of New Caledonia; from Permian-Mesozoic Southeast Gondwanaland active margin to Cenozoic obduction and supergene evolution
}

\footnotetext{
${ }^{1}$ Pôle Pluri-disciplinaire de la Matière et de l'Environnement-EA 3325, University of New Caledonia, BP R4, 98851 Noumea cedex, New Caledonia.E-mail:dominique.cluzel@univ-nc.nc; maurizot@canl.nc; julien.collot@gouv.nc; brice.sevin@gouv.nc

${ }^{2}$ B.R.G.M. Nouvelle-Calédonie, BP 56, 98845 Nouméa cedex, New Caledonia

${ }^{3}$ Service de la Géologie de Nouvelle-Calédonie, Direction de l'industrie, des mines et de l'énergie de Nouvelle-Calédonie, B.P. 465 - 98845 Nouméa cedex, New Caledonia.
}

The geological evolution of New Caledonia may be divided into three phases. The Gondwanan phase (Permian-Early Cretaceous), is marked by subduction along the SE Gondwaland margin. At that time, protoNew Caledonia was located in a fore-arc region in which volcanic-arc detritus accumulated; whilst accretion and subduction of oceanic and terrigenous material formed an accretionary complex metamorphosed into the blueschist facies. During the Late Cretaceous-Eocene, marginal rifting isolated New Caledonia, and after a short period of shallow water terrigenous sedimentation associated with minor volcanic activity, only pelagic sediments accumulated. A new NE-dipping subduction appeared to the E of New Caledonia at the PaleoceneEocene boundary, it generated the eclogite-blueschist complex of northern New Caledonia, consumed the eastern Australian Plate, and eventually ended with Late Eocene obduction when the Norfolk Ridge blocked the subduction zone. Finally, during the post-Eocene phase, New Caledonia definitively emerged; this episode mainly corresponds to prominent regolith development and minor tectonic events that lead to the present morphology and to the development of supergene nickel ores.

\section{Introduction}

Since Paris' geological synthesis of New Caledonia (Paris, 1981), advances in analytical methodologies and the application of the terrane concept by Aitchison et al. (1995a, b), Meffre (1995) and Meffre et al. (1996) has allowed a reappraisal of the regional geology. During the last thirty years, research groups or individuals from France, Australia, New Zealand and the USA have addressed several points of the geology of New Caledonia and proposed new interpretations; in addition, the recent creation (2006) of the Geological Survey of
New Caledonia has provided new impetus and opportunity to gather new field data, harmonise and synthesise already mapped areas, and create geological databases; therefore, knowledge of the geology of New Caledonia has made significant progress.

Since earliest Permian time, the age of New Caledonia's oldest rocks (Aitchison et al., 1998), three phases of development have been recognised: Permian-Early Cretaceous, Late Cretaceous-Eocene, and Oligocene-Holocene. The oldest is related to the evolution of the SE Gondwanaland active margin, Mesozoic marginal basin opening and subsequent closure; the second corresponds to the rifting that isolated slices of the older Gondwanaland margin and extends into the Cenozoic convergence that eventually ends with Late Eocene obduction; the third mainly corresponds to the supergene evolution of New Caledonia and involvement of the Australian Plate in the New Hebrides (Vanuatu) subduction zone. This article presents a simplified review of the geological evolution of New Caledonia mainly based upon recently published data.

Key for abbreviations: MORB: mid-oceanic ridge basalt; EMORB: enriched (or undepleted) MORB; OIB: oceanic island basalt; BABB: back-arc basin basalt; IAT: island-arc tholeiite; HP-LT: high pressure-low temperature (metamorphic rocks).

\section{New Caledonia in the framework of the Southwest Pacific}

New Caledonia is located within a complex set of marginal basins and "continental" or volcanic-arc ridges (Figure 1). It is composed of several islands that are parts of the Norfolk and Loyalty ridges. The main island (or "Grande Terre") belongs to the Norfolk Ridge, which is connected southward to the large continental plateau that also bears New Zealand. The Belep Islands to the $\mathrm{N}$ and Isle of Pines to the $\mathrm{S}$ of the main island also belong to the Norfolk Ridge. In contrast, the Loyalty Islands represent the emerged part of a sinuous submarine ridge (the Loyalty Ridge) that runs more or less continuously parallel to the Norfolk Ridge over more than $1,500 \mathrm{~km}$, from the d'Entrecasteaux Zone (W of Espiritu Santo,Vanuatu) in the N, to the Cook Fracture Zone in the S (Figure 1). Between the Loyalty and Norfolk ridges, the Loyalty Basin is a narrow, $1.5-3 \mathrm{~km}$ deep, oceanic 


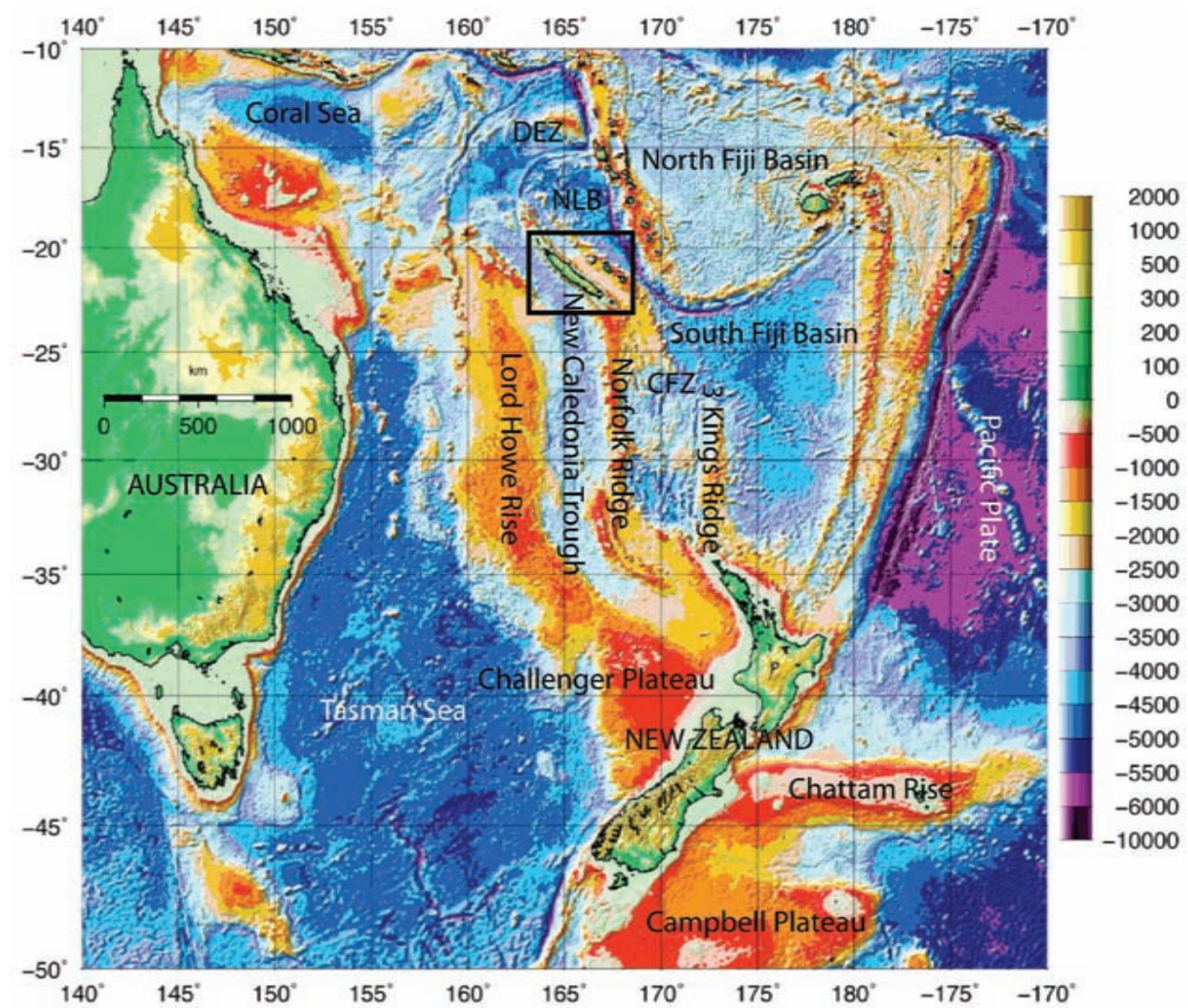

Figure 1 Bathymetric map of the SW Pacific (Smith and Sandwell, 1997). DEZ: D'Entrecasteaux Zone; NLB: North Loyalty Basin; CFZ: Cook Fracture Zone.

basin partly filled with $1-3 \mathrm{~km}$ of post-Eocene (?) sediments. The NE dip of the Moho, and geometry of seismic reflectors within the sedimentary filling of the basin (Bitoun and Récy, 1982) (Figure 2), are evidence of syn- and post-obduction infill. Over more than 500 $\mathrm{km}$ along the E coast of New Caledonia, a positive gravity anomaly $(>+100 \mathrm{mGal}$ ) (see below) marks the occurrence of a large elongated body of dense rocks, which has been interpreted as the root of the Peridotite Nappe (see below; Figure 3), the latter is thought to be in continuity with the oceanic lithosphere of the Loyalty Basin (Collot et al., 1987).

To the W and SW of the Grande Terre, the New Caledonia Basin (Figure 4) is at present based upon thinned continental crust in its

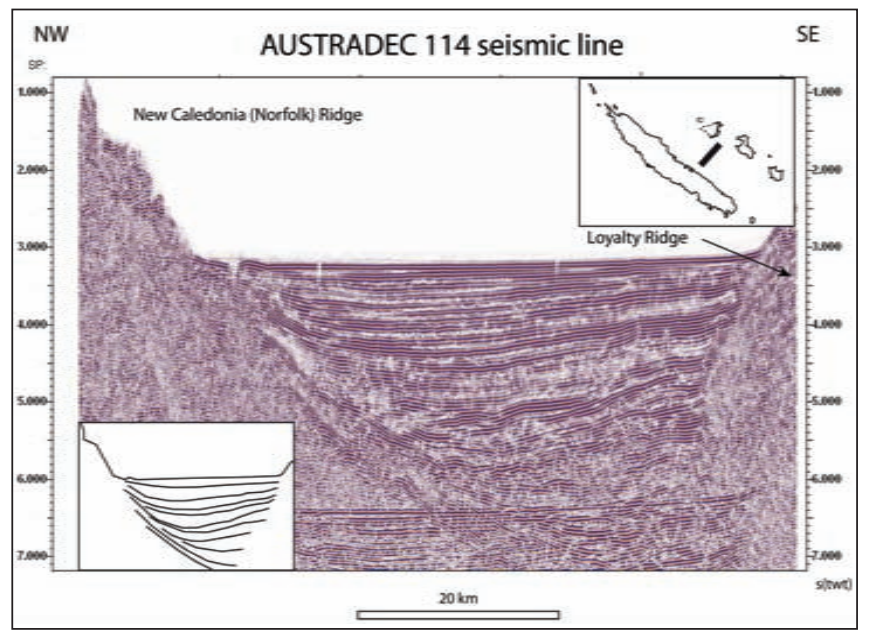

Figure 2 Seismic profile of the Loyalty Basin (Austradec 114) (after Schor et al., 1971; Pontoise et al., 1982). northern part, and oceanic crust in its southern part (Symonds et al., 1999; Auzende et al., 2000; Klingelhoefer et al., 2007). In the northern part of the basin, the pre-Cenozoic sedimentary infill shows evidence for half-graben structures that may be related to Late Cretaceous rifting. Pre-Oligocene reflectors (Figure 4) (Collot et al., 2008) and the Moho as well dip gently to the NE (Klingelhoefer et al., 2007). This may support the hypothesis of an attempted underthrusting (or continental subduction) of the northern Lord Howe Rise below New Caledonia (Cluzel et al., 2005). In contrast, the Oligocene westward onlapping sequence that rests horizontally above a gently NE dipping surface of unconformity (Figure 4), is consistent with the static infill of the basin by post-tilt, and thus post-obduction erosion products (Collot et al., 2008)

Similar to New Zealand, the main island of New Caledonia is a complex mosaic of volcanic, sedimentary and metamorphic terranes (Figures 5 and 6). New Caledonian terranes were assembled during two major tectonic episodes; an Early Cretaceous tectonic collage, which may be time-correlated with the Rangitata Orogeny of New Zealand (Fleming, 1969); and a Paleocene-Late Eocene subduction followed by obduction (Avias, 1967; Paris, 1981; Collot et al., 1987; Aitchison et al., 1995a). Both events included periods of high-pressure metamorphism and are therefore thought to

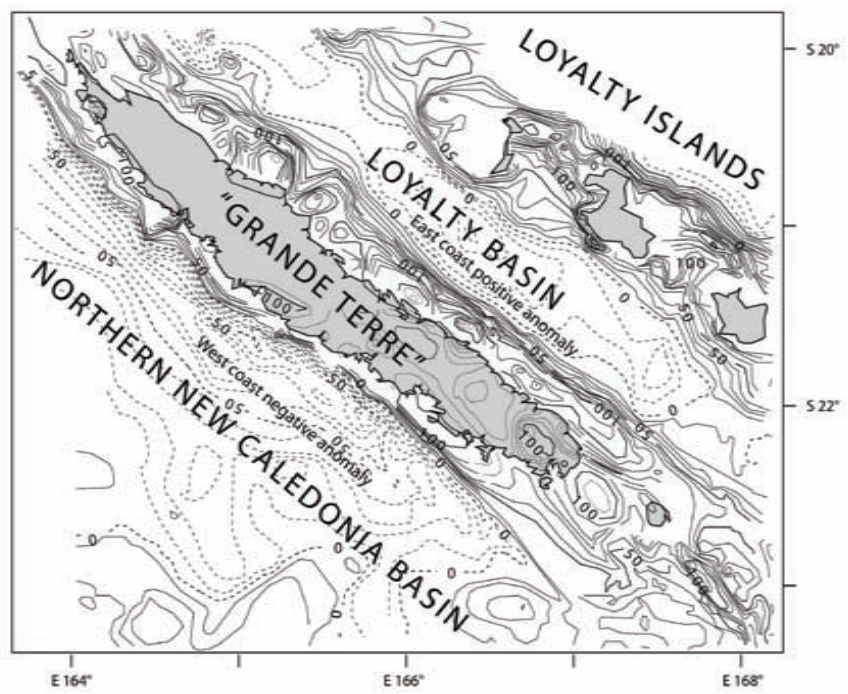

Figure 3 Free air anomaly gravity map of New Caledonia and adjacent basins (after Collot et al., 1987; Van de Beuque, 1999) to show the prominent asymmetry of the gravity field in New Caledonia. Plain lines: positive anomaly; doted lines: negative anomaly. The $E$ coast positive anomaly is related to the occurrence of peridotites at shallow depth below the eastern lagoon; whilst the negative anomaly of the $W$ coast is related to the $>7 \mathrm{~km}$ sediment thickness in the New Caledonia Basin. 


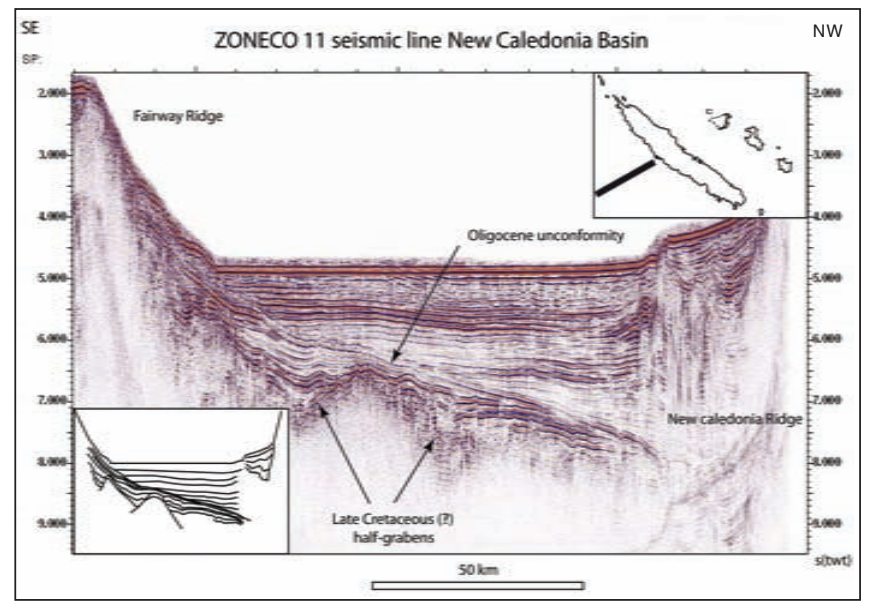

Figure 4 Seismic profile of New Caledonia Basin (ZONECO 11) (Klingelhoefer et al., 2007).

have occurred in connection with plate convergence in subduction zones.

\section{Pre-Late Cretaceous geology of New Caledonia: the Gondwanaland period}

Two major terrane groups are distributed along the length of New Caledonia (Figure 5): an older, late Permian-Early Cretaceous group of three sub parallel, elongate terranes on the $\mathrm{W}$ coast (Teremba) and in the central mountain range (Koh-Central, and Boghen); and a younger Late Cretaceous-Eocene group, overlying the latter, that formed in response to break-up, drift, convergence and subsequent collision of an island arc (Aitchison et al, 1995a). The pre-Late Cretaceous terranes were formed during a period of subduction/ accretion, and show closest biostratigraphic correspondence with Eastern Province terranes of New Zealand.

The three older terranes that form the central mountains of New Caledonia are as follows:

\section{The Koh-Central Terrane}

The Koh-Central Terrane is formed of an "oceanic" basement overlain by a thick volcanosedimentary cover. A disrupted, Early Permian (Aitchison et al., 1998) ophiolite suite (Koh Ophiolite) occurs locally along the centre of the island, comprising gabbro, dolerite, rare plagiogranite, IAT, low-Ca boninite pillow basalts, and undated cherts directly overlying the pillow basalts. The Koh Ophiolite rocks are overlain by a thick succession of volcanosedimentary rocks: black shale, volcaniclastic turbidite (greywacke), siltstone and chert (Meffre et al., 1996). The black shales are several hundred metres thick, whilst greywackes are generally associated with 20-50\% argillite and locally with chert, conferring this terrane a distal and deep-water character. The greywackes are exclusively composed of volcanic lithic (andesite, dacite and basalt) and mineral clasts (feldspar, quartz, amphibole, etc.), whilst plutonic clasts are generally absent, except for one locality (late Early Cretaceous). In general, fossils are extremely rare and poorly preserved; however, scarce Middle Triassic (Anisian), and Late Jurassic faunas have been correlated with those of the New Zealand Murihiku Terrane (Campbell et al., 1985; Meffre, 1995). A fossiliferous succession at Pouembout, formerly correlated with the Late Jurassic, is now considered Early Cretaceous (Adams et al., 2009).

\section{Teremba Terrane}

The Teremba Terrane comprises a succession of very low-grade (zeolite facies), Late Permian-mid-Jurassic, shallow-water, volcaniclastic (calc-alkaline, island arc-derived, andesitic) sedimentary rocks and volcanics (andesites, dacites and rhyolites). The sedimentary rocks are typically medium grained greywackes with only minor $(<10 \%)$ intercalated argillite, some shallow water volcaniclastic conglomerate and rare black shale, a few tens of metres thick. The mineral, geochemical and isotopic composition of greywackes is closely similar to that of the Koh-Central Terrane (Adams et al., 2009), similarly lack plutonic clasts and most probably come from the same source. In contrast with the Central Terrane, this terrane contains abundant faunas resembling those of the Murihiku Terrane of New Zealand (Grant-Mackie et al., 1977; Paris 1981; Campbell, 1984; Ballance and Campbell, 1993).

\section{The Boghen Terrane (the "ante-Permien" of Paris, 1981)}

The Boghen Terrane is a subduction complex comprising schistose unfossiliferous, volcano-sedimentary rocks (pillow basalts, chert,

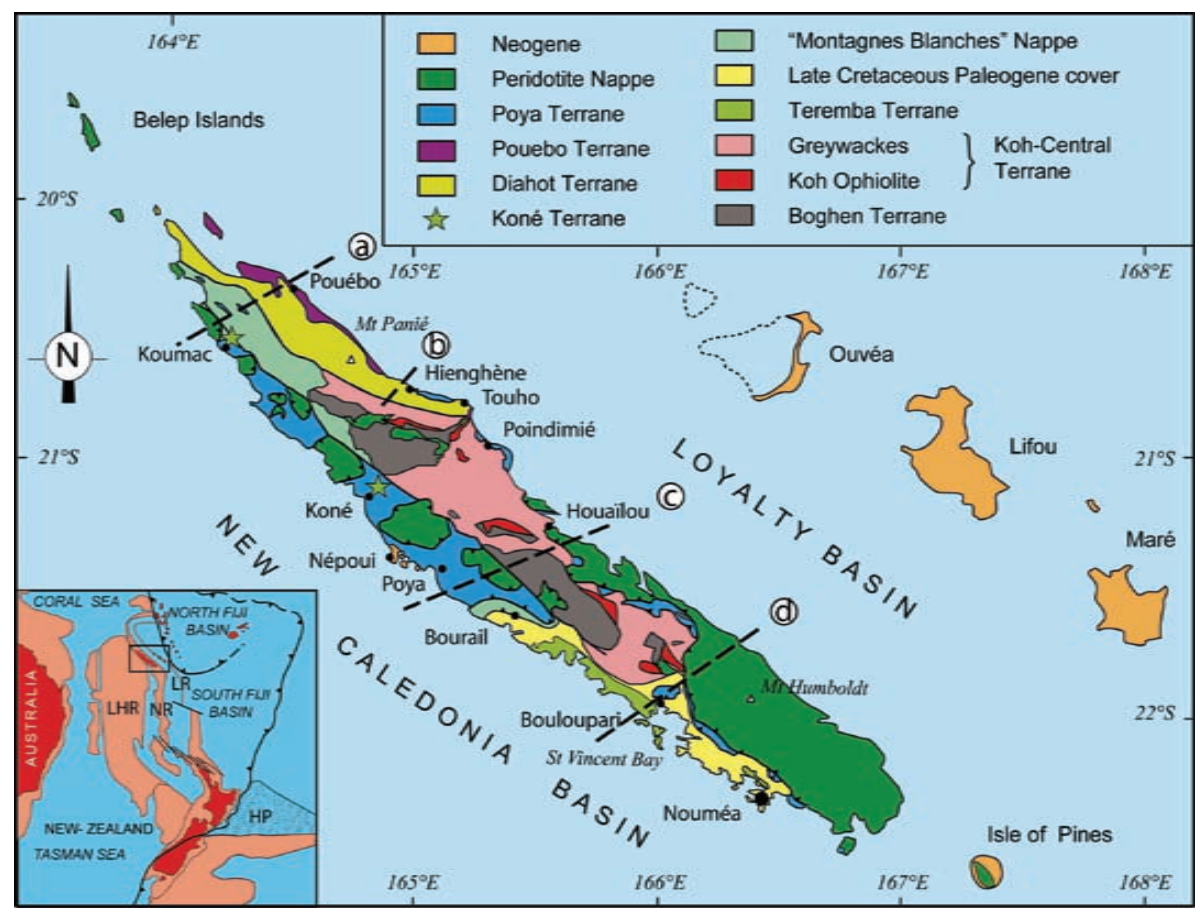

Figure 5 Tectonostratigraphic terrane map of New Caledonia (after Cluzel et al., 1999; Maurizot and Vendé-Leclerc, 2009). For a more detailed geological map of New Caledonia, see: http://dimenc.gouv.nc/portal/page/portal/dimenc/librairie/documents/telechargement/ NC_1000000_A1.pdf). 


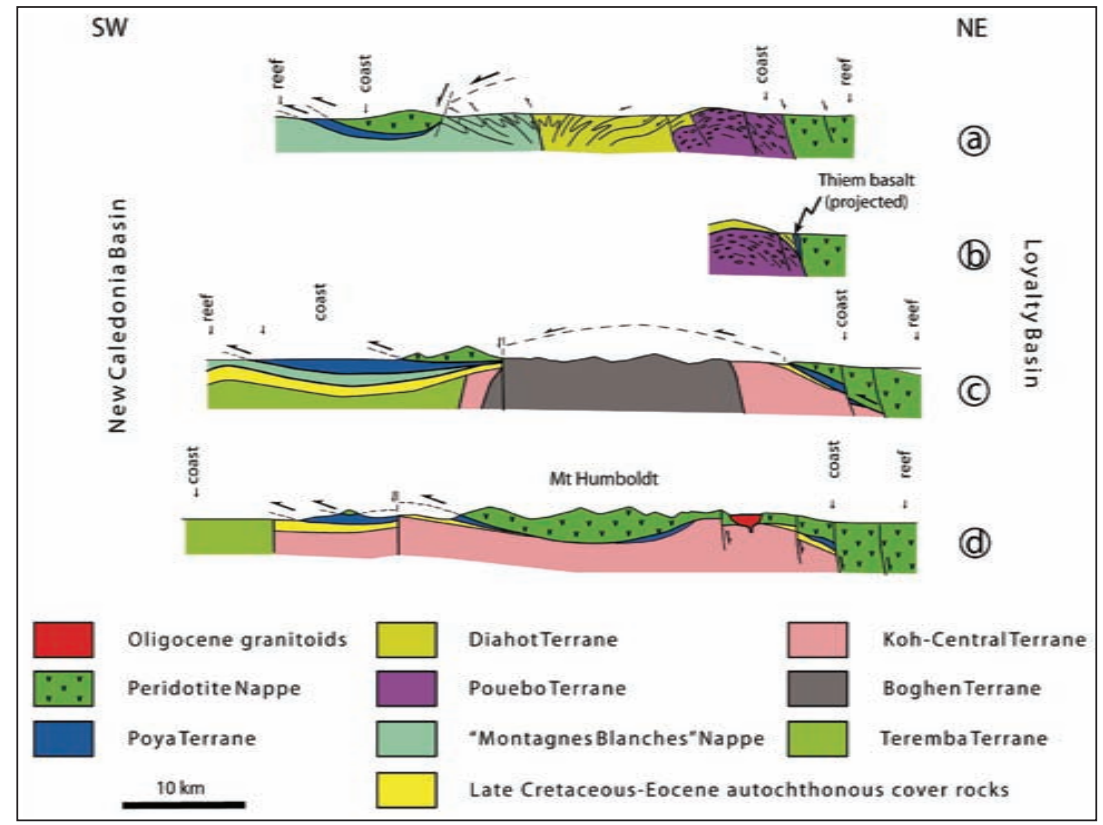

Figure 6 Simplified cross sections of New Caledonia to show the "basement" terranes overlain by Late Cretaceous to Eocene unconformable sedimentary cover, in turn overthrust by mafic (Poya Terrane) and ultramafic (Peridotite Nappe) allochthons (after Cluzel et al., 2001). For location, see Figure 5.

black shale, sandstone, tuffs, turbiditic greywackes, mafic melange and peridotite/serpentinite), at a metamorphic grade (lower greenschist to blueschist facies) that is notably higher than the adjacent terranes. Late Jurassic metamorphic ages (c. $150 \mathrm{Ma}$, whole-rock K-Ar) of the blueschists and metabasalts (Blake et al., 1977) suggest a minimum mid-Jurassic age for this terrane. However, Early Jurassic (Cluzel and Meffre, 2002) and more recently Early Cretaceous (c. $135 \mathrm{Ma}$ ) detrital zircon ages (Adams et al., 2009) set a maximum Early Cretaceous depositional age for the original sediments (see also Bryan et al., 2012).

\section{Reconstruction of the Southeast Gondwanaland active margin in New Caledonia}

Because Triassic-Early Cretaceous shallow-water volcaniclastic sediments (Teremba) occur to the $\mathrm{W}$, and deeper-water sediments (with the same origin; Koh-Central) to the E and, volcanic rocks and shallow intrusions are absent in the Koh-Central Terrane, Meffre (1995) and Cluzel and Meffre (2002) have suggested that the Teremba and Central terranes are the onshore and offshore parts of the same fore-arc basin respectively. This view is also supported by a westwards-increasing metamorphic gradient in the HP-LT Boghen Terrane (Guérangé et al., 1975; Paris, 1981), thus suggesting westwards-dipping Mesozoic subduction. At present, the corresponding Permian-Mesozoic volcanic arc is likely buried below younger sediments of the Lord Howe Rise (Figure 1).

In contrast with New Zealand where Mesozoic terranes derive at least partly from the erosion of mainland Australia, the PermianMesozoic volcaniclastic sedimentary rocks in New Caledonia mainly come from an intra-oceanic volcanic arc and contain unimodal zircon populations with about the same age as the enclosing sediment (Adams et al., 2009). This view is supported by the endemism of Triassic faunas and floras that is shared with New Zealand easternmost terranes. However, a contribution of continental rocks is present in sandstones associated with black shales that are intercalated at two levels of the sequence in the mid-Triassic and Late Jurassic. To account for zircon provenance, geochemical and isotopic features of volcanic and volcaniclastic rocks, and a possible northern origin of Koh Ophiolite rocks recorded by paleomagnetic data (Ali and Aitchison, 2000) as well, it has been suggested that proto-New Caledonia formed the eastern edge of a volcanic-arc and marginal basin system along the SE Gondwanaland margin. The marginal basin (in which deep-sea fans fed by mainland Australia accumulated) opened during the Permian-Triassic and closed obliquely during the Jurassic-Early Cretaceous to reach its present location marked by the Dun Mountain Suture (Adams et al., 2009).

\section{Late Cretaceous-Eocene phase: from marginal rifting to obduction}

Late Cretaceous: the marginal rifting

Overlying the three above-mentioned terranes with angular unconformity, there is a prominent Late Cretaceous (Coniacian-Campanian) (Paris, 1981), volcanosedimentary unit (classically referred to as "Formation à charbon"), which is composed of fining upwards marine shallow water sandstone, coal-bearing siltstone, tuffs and volcanic rocks (Figure 7) that accumulated in a tidal-zone or a near shore deltaic environment. The Late Cretaceous marine siltstones contain endemic faunas (ammonites and inocerams) (see Paris, 1981) that indicate an isolation from Australia, which is confirmed by the local provenance of detrital zircon populations (Cluzel et al., 2011). The pre-Coniacian unconformity post-dates the final amalgamation of the three aforementioned terranes. Exhumation of high-pressure metamorphic rocks of the Boghen Terrane thus occurred between the Barremian (c. 130 Ma; Adams et al., 2009) and the Coniacian (c. 89 Ma). Mafic and felsic volcanic rocks and tuffs occur near the base of the Formation à charbon (preCampanian), U-Pb dating of zircons extracted from a rhyolite flow there (88.4 Ma; Nicholson et al., 2011) confirms the Coniacian age of the Late Cretaceous transgression. The geochemical features of Late Cretaceous volcanic rocks contrast with that of pre-Late Cretaceous terranes. Whilst the latter are clearly related to an intraoceanic arc, the Coniacian-Santonian basalts and felsic volcanics of the former display evidence for subduction affinity and intraplate magmatism as well, with some transitional features. The volcanic rocks have been interpreted as a result of regional W-dipping subduction (Nicholson et al., 2011); however, the occurrence of contemporaneous bimodal arc- and rift-related volcanic rocks, and a mixing trend between them is a common feature of rifted active margins in which mafic and felsic magmas are produced by partial melting of a previously metasomatised mantle wedge and the lower continental crust respectively (Bryan et al., 1997; Cluzel et al., 2011). The end of volcanic activity in New Caledonia which coincides with Maastrichtian-Paleocene thermal subsidence (Aitchison et al., 1995a) is consistent with the latter interpretation.

The magmatic activity ceased before the Campanian and is thus restricted to the 89-83.5 Ma interval, i.e., magmatic activity ceased 


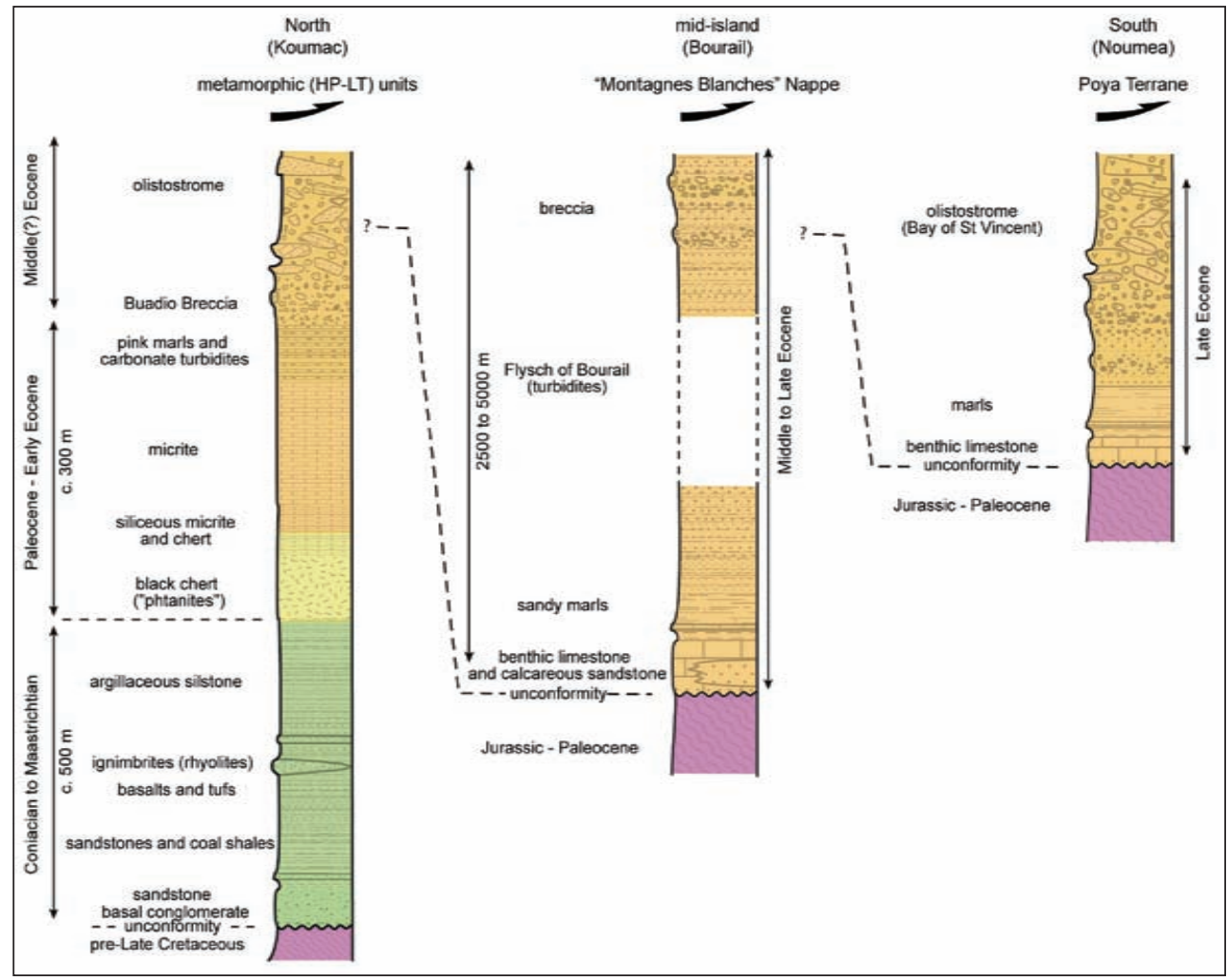

Figure 7 A comparison of Eocene sedimentary evolution in northern, mid- and southern New Caledonia to show the southward migration of the Eocene unconformity and syntectonic foreland basins (after Cluzel et al., 2001).

when the Tasman Sea (Hayes and Ringis, 1973) and South Loyalty marginal basins (Cluzel et al, 2001) opened. Meanwhile, sedimentation evolved from shallow-water marine sandstone and siltstone toward pelagic siliceous pelite (Maastrichtian), and micrite (Paleocene-Early or mid-Eocene depending upon diachronous Eocene pre-obduction events). This environmental change may be related to the thermal subsidence that followed the marginal rifting and complete submersion of New Caledonia (Aitchison et al., 1995a; Cluzel et al., 2011), a similar evolution is recorded from the Lord Howe Rise that was above sea level until the Maastrichtian and thereafter was the locus of pelagic siliceous sedimentation (McDougall and Van Der Lingen, 1974).

In northern New Caledonia, development of the Eocene highpressure metamorphic complex (see below) has dramatically erased most of the primary features of the protoliths. However, the bulk of the Late Cretaceous-mid-Eocene sequence, although metamorphosed to eclogite or blueschist facies, is similar to the unmetamorphosed sequence of the Noumea area; although Late Cretaceous carbonaceous sediments there are considered more distal (Maurizot et al., 1989).

A triple provenance is necessary to account for the composition of Coniacian-Santonian sandstones. Contemporaneous volcanic activity provided most of the felsic component and rare volcanic zircon of the same age; a prominent mid-Cretaceous population (110-95 $\mathrm{Ma}$ ) is puzzling because rocks of this age are extremely rare in New Caledonia (Cluzel et al., 2010), unless they were completely eroded away before the Late Cretaceous; the older part of the detrital zircon age spectrum very closely resembles those of the sandstones of the Boghen and Koh-Central terranes and has been provided by the erosion of directly underlying basement rocks. Therefore, at variance with previous interpretations, there is no need to advocate an
Australian provenance to account for the occurrence of Precambrian detrital zircons (Aronson and Tilton, 1971; Aitchison et al., 1998). New Caledonia was already isolated from Australia by the Late Cretaceous, a feature consistent with the development of faunal and floral endemism at that time (Cluzel et al., 2011).

\section{Paleocene-Early Eocene: long-term subsidence and pelagic sedimentation}

Paleocene black cherts and minor argillite that transitionally overlie the Formation à charbon are classically referred to as "phtanites" in New Caledonia. These pelagic sediments are formed of cryptocrystalline silica, sponge spicules, radiolarians, and rare plagioclase grains. Phtanite deposition marks the end of terrigenous inputs and a complete submersion of $\mathrm{New}$ Caledonia; it originally formed at a low latitude and in a cool climate. Progressive global warming (Zachos et al., 2001) and northward drift during the Paleocene probably drove New Caledonia progressively out of the southern circum-polar siliceous ooze belt and allowed siliceous micrite to form; thereafter, the amount of silica progressively decreased and pure micrite accumulated during the Eocene (Figure 7). During that period, the New Caledonia Ridge was a stable isolated plateau in relatively deep waters, a situation that drastically changed during the late Early-Late Eocene, when intrabasinal breccias diachronously appeared and migrated southwards, and New Caledonia emerged again (see below).

\section{Eocene foreland basins}

In the areas where an Eocene sequence (Figure 7) has been preserved, in the $\mathrm{N}$ of the island (near Koumac) and in olistoliths of the Baie de St Vincent Olistostrome (south), the pelagic white micrite abruptly changes upwards into late Ypresian (c. $50 \mathrm{Ma}$ ) pink marls (Maurizot, 2011). This change records input of illite and minor hematite in the basin, and likely signals local emersion and weathering. Along the Koumac-Ouegoa section in the $\mathrm{N}$ of the island, $\mathrm{SW}$ verging stacked and isoclinally folded units result from in-sequence duplexing of the Late Cretaceous-Eocene sedimentary cover; therefore, the stacked units record a NE-ward change in basin geometry. The pink marls locally show rhythmical bedding and evidence for turbiditic sedimentation that signals the appearance of a slope in the basin; upwards, i.e., NE-wards in the stacked units, increasing intrabasinal instability is recorded by the occurrence of monogenetic limestone breccia, that rework the pink marl and white micrite as well. This breccia is quickly followed by intraformational polygenic breccia that mainly reworks the immediately underlying limestone. Finally, the Buadio breccia, which is composed of limestone and phtanite clasts changes upwards into an olistostrome formed of $100 \mathrm{~m}$ - to $1000 \mathrm{~m}$ - 
scale olistoliths enclosed in a matrix of coarse conglomerate. The evolution of clasts provenance and size records the progressive involvement of deeper (i.e., older) parts of the sedimentary cover in a series of short-lived syntectonic basins located in front of SW- or SSW-prograding thrusts (Maurizot, 2011).

In contrast, in the $S$ of the island (from Bourail to Noumea), unconformable shallow water limestone forms the base of a mid- to upper Eocene turbidite sequence that rests upon eroded older rocks (Figure 7). Pre-mid-Late Eocene erosion has been interpreted as a consequence of emersion due to fore-arc bulge (Cluzel et al., 1998) and foreland basin inception. The basal limestone youngs southward from Early to Late Eocene (Figure 7), a feature consistent with the progressive involvement and northward subduction of the northern tip of Norfolk Ridge (Cluzel et al., 2001). The 3-5 km-thick turbidite sequence that overlies the basal limestone is referred to as "Bourail Flysch" (Paris, 1981). The arenites and breccias are mainly composed of upwards coarsening clasts of various lithologies that include easily recognisable angular fragments of Paleocene limestone and black chert (phtanite). In contrast with breccias of the northern units, which only contain elements derived from the autochthonous sedimentary cover, the Bourail Flysch contains an upwards increasing amount of mineral and lithic clasts derived from a mafic source. In the upper third of the turbidite sequence, arenites may contain up to 50\% clinopyroxene clasts. The geochemical features of mineral (clinopyroxene) and lithic clasts (basalt, dolerite and red chert) are closely similar to those of Poya Terrane rocks, which are therefore the most likely source (Cluzel et al., 2001). The top of the Bourail Flysch is an olistostrome, which in turn is overthrust by the allochthonous Poya Terrane (see below).

Thus, southward younging, syntectonic Eocene sequences record the in-sequence overthrusting of the Late Cretaceous-Early Eocene sedimentary cover of the northern Norfolk Ridge, and in southern units, the final out-of-sequence overthrusting of the Poya Terrane (Figure 8). It is worth noting that no ultramafic clasts have been recorded in the foreland basin; it clearly remained out of reach of ultramafic detritus issued from the fore-arc mantle lithosphere (i.e., the future Peridotite Nappe) that was obducted later.

\section{The subduction-obduction complex}

The occurrence and tectonic features of ultramafic and mafic allochthons, age migration of foreland basins, polarity and exhumation kinematics of the HP-LT metamorphic complex, all suggest that Late Eocene obduction was preceded by $\mathrm{N}$ - or NE-dipping subduction.

\section{Peridotite Nappe}

From a geological and an economic point of view as well, the Peridotite Nappe (Avias, 1967) is certainly the most prominent terrane of New Caledonia as it represents more than $25 \%$ of the surface of the Grande Terre and is of major economic importance for the country. This dominantly ultramafic terrane consists of a southern unit, the "Massif du Sud" and a number of tectonic klippes spread along the $\mathrm{W}$ coast of the island (Figures 5 and 6). This unit is dominantly formed of upper mantle rocks (harzburgite and rare lherzolite) with minor ultramafic (pyroxenite, wehrlite and dunite) and mafic (layered gabbro) cumulates (Prinzhoffer, 1981). A high temperature foliation associated with dunite/harzburgite layering exists throughout the terrane, and it generally dips gently (i.e., $<20^{\circ}$ ) forming broad gentle folds. This foliation locally bears a high-temperature mineral/
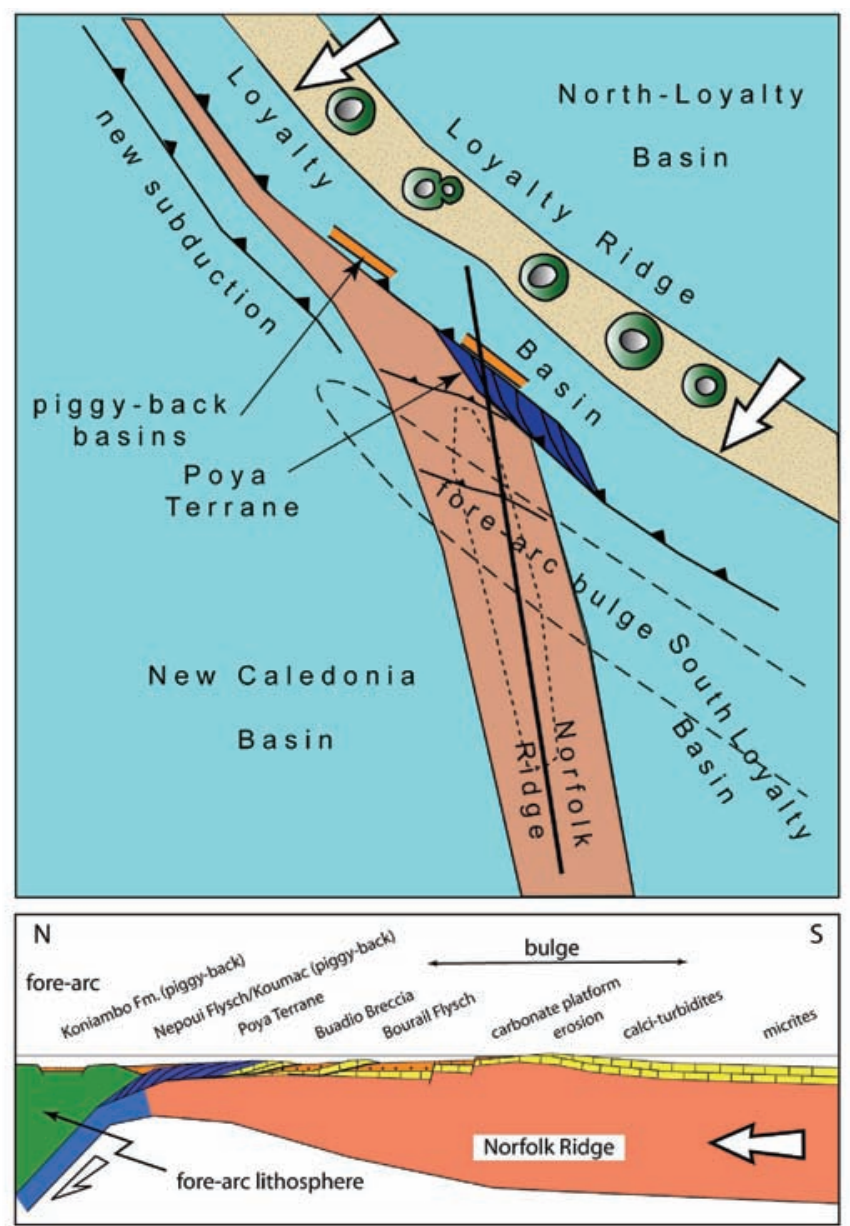

Figure 8 Tentative paleo-geographic reconstruction of New Caledonia and the Loyalty Ridge during Eocene time, to show the development of foreland and piggy-back basins, and southward migration of sedimentary facies during the pre-obduction period.

stretching lineation oriented N-S; it is marked by the preferred orientation of orthopyroxene in harzburgite, and chromite aggregates in dunite (Prinzhoffer et al., 1980). This lineation associated with a gently dipping foliation probably results from the detachment-like tectonics that occurs at the base of the newly formed lithosphere (the $1,200^{\circ} \mathrm{C}$ isotherm) close to the oceanic ridge, as a consequence of differential motion between lithosphere and asthenosphere. Therefore, owing to the average $\mathrm{N}-\mathrm{S}$ trend of the stretching lineation, the oceanic ridge that generated the ophiolite is thought to have had an E-W trend.

The upper mantle and lower oceanic crust rocks reflect a complex history that includes several stages of melting, rock-melt interaction, and re-melting (Marchesi et al., 2009; Ulrich et al., 2010) that finally lead to an extreme overall depletion. Therefore, age constraints on ophiolite formation are scarce, and except a few poorly reliable $\mathrm{K}-\mathrm{Ar}$ ages (120-50 Ma; Prinzhoffer, 1981), the only direct dating has been attempted by Prinzhoffer (1987), who provided a 131 \pm 5 Ma age based on a Sm-Nd rock-mineral isochron from a gabbro of the Montagne des Sources (Massif du Sud). An Early Cretaceous age is problematical considering the geodynamic setting of the SW Pacific at that time and requires validation by other methods.

The Peridotite Nappe is crosscut at all levels by Early Eocene basalt (dolerite), micro-diorite and diverse felsic dykes emplaced within a narrow span of time (55-50 Ma; U-Pb dating of zircon) that 
suggest a minimum Late Paleocene age for the oceanic lithosphere (Cluzel et al., 2006). Dolerite dykes are dominantly IAT-like and probably represent the youngest product of magmatic-arc activity (c. $50 \mathrm{Ma}$, whole rock K-Ar; Prinzhoffer, 1981). Microdiorite results from the hydrous melting of a similar supra-subduction source whereas most felsic dykes display the geochemical features of slab melts (Cluzel et al., 2006). Thus, a transient thermal pulse in the fore-arc region during earliest Eocene time probably generated this short-lived magmatic event with arc and fore-arc magmatic affinities.

Locally, amphibolite lenses, c. $200 \times 10-50 \mathrm{~m}$, appear at the base of the serpentinite sole, above Poya basalt. Back-arc basin basalts (BABB) geochemical composition and ${ }^{40} \mathrm{Ar}-{ }^{39} \mathrm{Ar}$ hornblende cooling ages at 56 Ma suggest that these amphibolites originated from the Poya Terrane basalts at, or near a spreading ridge at subduction inception, a feature consistent with synchronous formation of the slab melts mentioned above (Cluzel et al., 2012).

Partial serpentinisation (20-60\%) appears throughout the Peridotite Nappe, it is generally interpreted as a consequence of cooling and low temperature hydration of the oceanic mantle lithosphere; in addition, a more extensive serpentinisation occurs in the tectonic sole with the development of porphyroclastic mylonite 20-200 m thick, which likely formed during obduction, and locally indicates SW-directed shearing. In general, the Peridotite Nappe overlies the Poya Terrane and the autochthonous rocks above a subhorizontal fault (Figure 6), with the very simple structure sharply contrasting with the complexity of underlying terranes.

\section{Poya Terrane}

The Poya Terrane is an allochthonous set of $\mathrm{m}$ - to km-scale upright tectonic slices of pillow and massive basalt ( $99 \%$ of the terrane) associated with thin inliers of bathyal sediment (red, black and green chert and argillite); it is always located below the Peridotite Nappe (Figures 1 and 2). The main body of this unit is located along the $\mathrm{W}$ coast where it is $10 \mathrm{~km}$ wide, and extends over a length of $250 \mathrm{~km}$ from Bourail to Koumac; smaller and less continuous units are located along the E coast (Figures 5 and 6).

Based upon paleomagnetic evidence, these rocks are thought to have erupted to form an oceanic floor (South Loyalty Basin; Cluzel et al., 2001) to the NE of New Caledonia, at a latitude c. $300 \mathrm{~km}$ to the $\mathrm{N}$ of its present location (Ali and Aitchison, 2000). Inliers of bathyal sedimentary rocks, which are closely associated with pillow basalts contain Campanian-latest Paleocene or earliest Eocene radiolarians (Aitchison et al., 1995b; Cluzel et al., 2001). Poya Terrane basalts are dominantly undepleted MORB (E-MORB), which represent remnants of an oceanic or marginal basin crust (Cluzel et al., 2001). Subordinate BABB and intra-oceanic alkaline basalts (OIB) display carbonate interpillow material with Late Paleocene-Early Eocene microfaunas. These basalts are highly vesicular, and often reddened; therefore, they probably represent seamount lavas erupted upon Late Cretaceous-Paleocene oceanic crust. K-Ar whole rock apparent ages that range from c. 61-38 Ma (Guillon and Gonord, 1972; Eissen et al., 1998), are young relative to fossil ages and are thus probably meaningless. These apparent ages probably reflect a complex evolution due to both excess argon input due to fluid-rock interaction during lithosphere cooling, and diverse thermal resetting phases.

Except in its northernmost occurrence along the E coast (Thiem basalt, SE of Hienghene) where blueschist facies minerals scarcely appear (Meffre, 1995), the Poya Terrane is not regionally metamorphosed and does not display any ductile deformation. The local occurrence of lower greenschist or zeolite facies mineral associations is likely due to intra-oceanic water-rock interaction referred to as ocean floor metamorphism (Nicholson et al., 2000). Slices of Poya Terrane rocks have been first scraped off the downgoing plate during E-dipping subduction of the South Loyalty Basin, then accreted in a fore-arc region (see below) and thereafter thrust onto New Caledonia during the Late Eocene, prior to the obduction of ultramafic rocks (Cluzel et al., 2001). Accretion of km-scale slices of coherent crustal material may be related to the Cordilleran-type ophiolite formation.

According to analog experiments for material transfer in accretionary wedges (Gutscher et al., 1998) the peeling of the upper part of the down-going slab remains a possibility, which may result either from an extreme roughness of the down-going plate, or more probably from a very shallow dip of the subduction zone. Offscrapping of the Poya Terrane in the Loyalty fore-arc probably took place because subduction started at, or near the oceanic ridge (Ulrich et al., 2010; Cluzel et al., 2012) and was buoyant at least at the beginning.

Small-scale piggy-back basins, represented by the Nepoui Flysch and Koumac Olistostrome are closely associated with the Poya basalt. Both basins are pinched between the Poya Terrane and the Peridotite Nappe. The Nepoui Flysch starts with 2-5 m-thick biocalcarenite of uncertain age (Bartonian-Priabonian; Meffre 1995; Cluzel, 1998) that rests directly upon serpentinite. Significantly, the basal limestone contains large benthic foraminifers, and some detrital serpentine and chromite grains. It is overlain by pale brown argillite, and alternating coarse arenite and dolomicrite. On top of arenite beds, thin layers or lenses of reworked red argillite very closely resemble those of the Poya Terrane. Arenite clasts are derived from three distinct sources: Poya Terrane basalt (clinopyroxene, ilmenite and magnetite), an adjacent shallow water platform (carbonate bioclasts), and serpentinite. It is worth noting that the arenites contain no fresh peridotite rock or mineral clasts such as chromite. The dolomicrite beds, $2-10 \mathrm{~cm}$ thick, have provided a Late Eocene (Priabonian) pelagic microfauna (Maurizot, unpublished data, 2009).

The Koumac Olistostrome, c. $300 \mathrm{~m}$ thick, is composed of several mass flow breccia units, 5-10 metres thick, composed of basalt boulders embedded in a matrix of sandy breccia made of pillow and chert fragments with some lenses of red blocky argillite. Basalt fragments display the same geochemical features as Poya basalt (EMORB; Cluzel et al., 2001). Occasionally, decimetre-sized clasts of felsic and amphibole rich magmatic rocks and scarce serpentinite appear in the breccia. These rocks closely resemble those of the Early Eocene dyke system of the Peridotite Nappe. On top of the mass flow unit, $50 \mathrm{~m}$ of whitish sands occur but contain a few basal basalt boulders. One single dolomicrite horizon, c. 3 metres thick, appears within the mass flow units which therefore resemble the Nepoui Flysch in terms of clast provenance and basinal conditions.

Both the Nepoui Flysch and Koumac Olistostrome may have accumulated in piggyback basins located near the boundary between the Poya Terrane and exhumed serpentinites of the fore-arc region (Figure 8).

\section{Kone Terrane}

Discrete slices of a parautochthonous Late Cretaceous hemipelagic unit composed of siltstone, argillite and chert, referred to as 
"Formation de Koné" (Carroué, 1972; Paris, 1981) occur near Koné and Koumac (Figure 5). The unit has no known basement, contains no carbonaceous material, and has more distal facies than the typical autochthonous rocks of the same age. Currently, it is situated above the Montagnes Blanches Nappe (see below), Paleocene autochthonous sedimentary rocks and below the allochthonous Poya Terrane and everywhere has faulted boundaries. It possibly accumulated originally on a continental slope, or directly upon older oceanic crust, to the NE of New Caledonia and was picked up and thrust upon New Caledonia by the Poya Terrane, and finally overthrust by the latter.

\section{The "Montagnes Blanches" Nappe}

The "Montagnes Blanches" Nappe (Maurizot, 2011) is systematically intercalated between the top of the Paleogene flysch and the overlying obducted ophiolite units throughout the Grande Terre. It consists of Late Cretaceous black argilites, cherts, overlain by Paleocene micrites passing upwards into Early Eocene calciturbidite. It represents an unmetamorphosed lateral equivalent of the Diahot Terrane. Named after the range marking the northern flank of the Bourail anticline (Figure 5), where it is particularly well exposed, this unit is parautochthonous and rooted in the Koumac area and allochthonous farther south. In the Bourail and Nouméa areas, the uppermost levels of the flysch contain elements of this allochthonous sedimentary unit broken up into olistoliths, as well as elements of the Poya Terrane.

\section{Eocene metamorphic complex}

The HP-LT metamorphic complex in the $\mathrm{N}$ of the island comprises the metamorphic Diahot and Pouebo terranes (Figure 1). In spite of a much higher metamorphic grade (blueschist and eclogite), the Diahot Terrane rocks do not greatly differ from the Cretaceous-Eocene sedimentary cover, although they have a more distal character during the Late Cretaceous. It shows the same Cenozoic sedimentary sequence except that the Eocene turbidite-olistostrome is dominantly composed of breccias, which started earlier than in the S (late Ypresian; c. $50 \mathrm{Ma}$; Maurizot, 2011), and characteristically do not contain any mafic rock. The Pouebo Terrane is a subduction melange composed of 0.1-100 m-scale boulders of mafic rocks derived from the Poya Terrane (Cluzel et al., 2001; Spandler et al., 2005), embedded in a meta-serpentine (talc-schist) or metasedimentary matrix. The Diahot Terrane rocks have been subducted at depth c. $50 \mathrm{~km}$ $\left(1.7 \mathrm{GPa}-550^{\circ} \mathrm{C}\right.$ ) (Fitzherbert et al., 2003; 2005) whereas eclogites in the Pouebo Terrane have metamorphic mineral associations which suggest a much higher grade and maximum burial depth of c. $80 \mathrm{~km}\left(2.4 \mathrm{GPa}-650^{\circ} \mathrm{C}\right)$ (Clarke et al., 1997; Carson et al., 1999, 2000). At present, the Pouebo Terrane, which was subducted at greater depth, appears in the core of a regional-scale foliation antiform wrapped by the Diahot Terrane (Figure 6) as shown by the occurrence of E-dipping Diahot carbonaceous schists, siliceous schists (metamorphosed "phtanites") and recrystallised limestones along the eastern shoreline between Hienghene and Touho (Maurizot et al., 1989; Cluzel et al., 1995a, b, 2001; Rawlings and Lister, 1999, 2002). In turn, the eastern flank of the antiformal structure is overlain by slices of the Poya Terrane (Thiem unit; Maurizot et al., 1985; Cluzel et al., 2001; Figures 5 and 6) and finally by the Peridotite Nappe, which is rooted in the Loyalty Basin (Collot et al., 1987). The regionalscale antiformal structure of the metamorphic complex may be due either to a late folding of the tectonic pile (Rawlings and Lister, 2002); or alternatively, to the exhumation of the high grade eclogitised melange (Pouebo Terrane) that dragged the overlying rocks (Diahot Terrane) towards the surface (Figure 9; Cluzel et al., 1995a, b; Baldwin et al., 2007). Along the Koumac-Pouebo section, i.e. from SW to NE across the island, the metamorphic grade changes abruptly in connection with SW-verging ductile thrusting; in contrast, it evolves much more gradually along strike, and blueschist facies rocks crop out to the SE of Poindimié (E coast; Figure 5). Therefore, exhumation of HP-LT rocks was likely to occur in a scissors- or fan-like fashion.

Thermochronological and radiochronological data allow the exhumation of the HP-LT complex to be better constrained. Eclogites of the Pouebo Terrane started to exhume at c. $44 \mathrm{Ma}(\mathrm{U}-\mathrm{Pb}$ age of zircon overgrowths; Spandler et al., 2005); whilst zircons of Diahot Terrane rocks display younger overgrowths at c. $38 \mathrm{Ma}$ (Cluzel et al., 2010). The closing temperature of phengite $\left(450^{\circ} \mathrm{C}\right)$ in both terranes is recorded by ${ }^{40} \mathrm{Ar}-{ }^{39} \mathrm{Ar}$ thermochronology at c. $36 \mathrm{Ma}$ (Ghent et al., 1994; Baldwin et al., 2007). Exhumation at c. $7 \mathrm{~km}$ depth occurred at c. $34 \pm 4 \mathrm{Ma}$ as shown by apatite fission track data (c. $85^{\circ} \mathrm{C}$; Baldwin et al., 2007; Figure 9).

\section{Loyalty Ridge}

The geology of the Loyalty Ridge is still poorly known due to the lack of basement outcrops and a thick carbonate cover. It may be extended northwards into the Southern D'Entrecasteaux Zone and is connected southwards to the Three Kings Ridge beyond the Cook Fracture Zone (Kroenke and Eade, 1982). Geophysical and swath bathymetry data indicate that this ridge is formed of seamounts, the

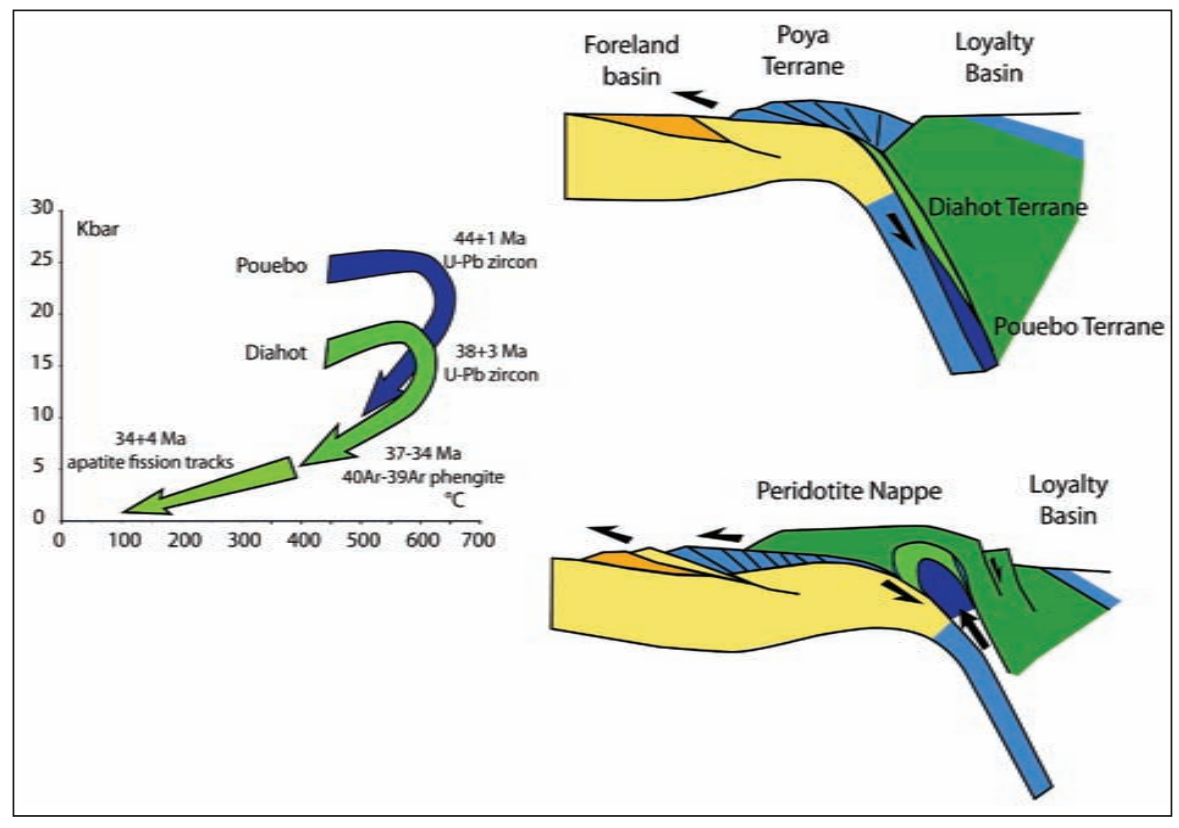

Figure 9 A conceptual model for the subduction and exhumation of the HP-LT terranes of New Caledonia to account for the P-T-t paths of Pouebo and Diahot terranes. 
size and spacing of which are similar to those of most island arcs, (Bitoun and Récy, 1982; Lafoy et al., 1996). Seamounts are overlain by Miocene limestone plateaus, which are in turn capped and fringed by Pliocene-Recent coral reefs. The Bougainville Seamount located at the eastern end of the South d'Entrecasteaux Ridge, has been drilled (ODP 831), and Eocene andesite was found underneath $700 \mathrm{~m}$ thick Oligocene to Holocene limestone (Dubois et al., 1988; Greene et al., 1994). In the North Loyalty Basin, at the DSDP 286 site, c. 500 mthick Middle-Late Eocene andesitic volcaniclastic turbidites have been drilled (Andrews et al., 1975). Because of these features, and in spite of lack of outcrop evidence, the Loyalty Ridge should be considered as an Eocene island arc and the North Loyalty Basin the associated back-arc basin (Maillet et al., 1983; Cluzel et al., 2001; Schellart et al., 2006; Paquette and Cluzel, 2007; Whattam et al., 2008; Whattam, 2009). Intra-oceanic alkaline (OIB; Baubron et al., 1976; Maurizot and Lafoy, 2003) basalt and dolerite that crop out on Mare Island were thought to represent the volcanic basement of the island (Rigolot, 1988). However, intraplate volcanism is younger that some of the carbonate cover and not older than Middle Miocene (Maurizot and Lafoy, 2003). In addition, the Late Miocene (11 Ma; Baubron et al., 1976) dolerite and basalt dykes that appear at the surface crosscut the limestone and develop contact metamorphism (Chevallier, 1968). Therefore, these basalts are unlikely to represent the basement of Loyalty Ridge; instead they may be part of a N-S trending hot spot trail and younger than the Loyalty Ridge itself (Meffre, 1995). The Loyalty Ridge is at present involved in the forearc bulge of the Vanuatu Arc which results in diachronous emersion and uplift of the Loyalty Islands (Dubois et al., 1974). Incipient oblique collision with the arc/trench system (Lafoy et al., 1996) results in the development of a complex fracture set (Bogdanov et al., 2011).

\section{Oligocene-Present: the post-obduction phase}

\section{Late Oligocene post-obduction plutonism}

In southern New Caledonia, post-obduction km-size plutons are intruded into the ultramafic allochthon and its autochthonous basement as well. U-Pb dating of magmatic zircons provided 27.5 and $24 \mathrm{Ma}$ (Late Oligocene) for St Louis granodiorite (near Noumea) and Koum-Borindi adamellite (E coast) respectively (Paquette and Cluzel, 2007) (Figure 6c). The high-K to medium-K calc-alkaline granitoids display the geochemical and isotopic features of volcanicarc magmas uncontaminated by crust-derived melts. These magmas were possibly generated during Oligocene subduction of the oceanic part of the northern New Caledonia Basin (Cluzel et al., 2005) that may also account for the north-eastward dip of the Moho (Klingelhoefer et al., 2007) (Figure 10). Although no alternative interpretation has been proposed for these granitoids, this model does not meet a general agreement (e.g., Sutherland et al., 2010). Strontium, $\mathrm{Nd}$ and $\mathrm{Pb}$ isotopic ratios indicate derivation from an isotopically homogeneous mantle wedge; but some variation in trace-element ratios uncorrelated to differentiation, are diagnostic of source heterogeneity. Prominent HREE depletion of some of the younger granitoids may be due to an equilibrium with garnet-bearing subcrustal material (granulite) found as xenoliths (Paquette and Cluzel, 2007); whilst a relative $\mathrm{Nb}$, Ta and $\mathrm{Hf}$ enrichment, irrespective of crystal fractionation, may be related to either a modest contamination

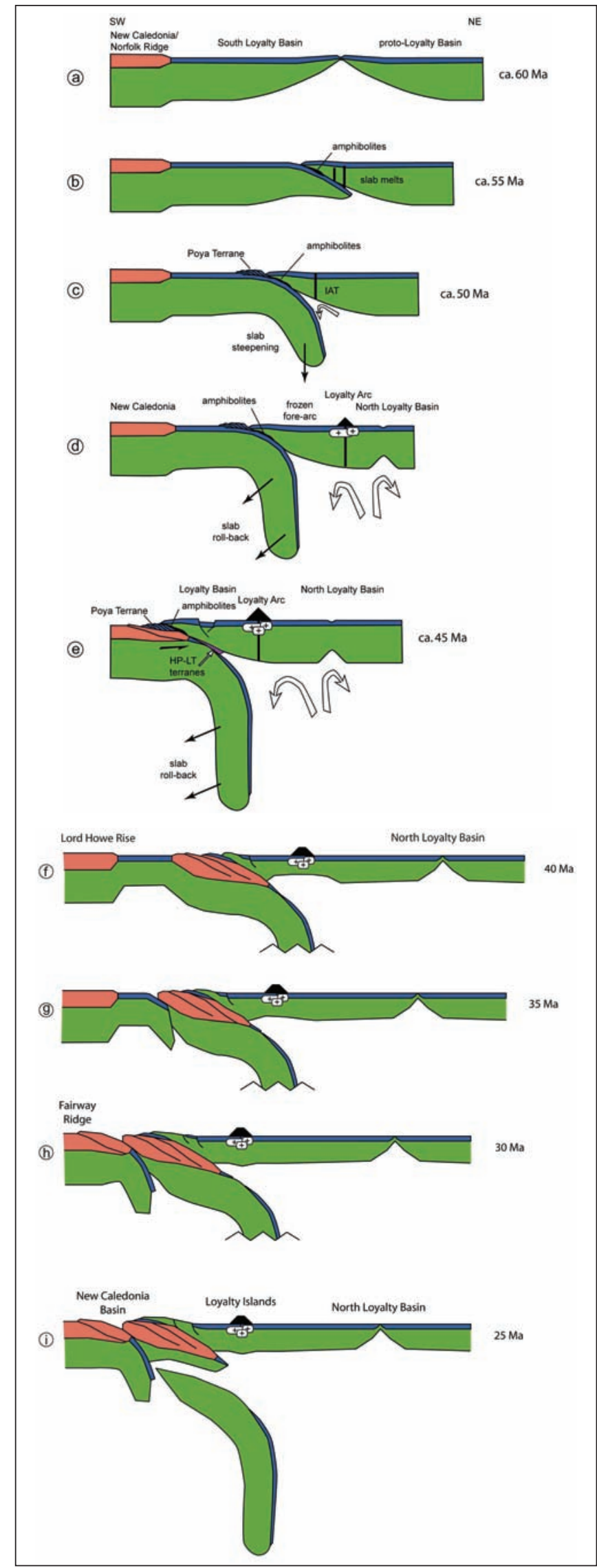

Figure 10 A model of lithospheric evolution of New Caledonia from Late Paleocene subduction inception to Late Oligocene slab break off. 
by previously underplated mafic material, heterogeneous hydration of the mantle wedge, or mixing with uplifted Nb-rich mantle. Postobduction slab break-off is advocated to account for sub-lithospheric mantle mixing and subsequent heterogeneity (Cluzel et al., 2005).

\section{Supergene evolution: a polyphase weathering history}

The emersion of New Caledonia during, or soon after obduction prevented marine sediments to accumulate except in coastal areas; instead, thick regolith developed and probably covered the whole island. Weathering profiles that develop upon peridotites are important not only because they record tectonic stability and hence are good proxies for regional dynamics, but also because they are important $\mathrm{Ni}$ resources. The regolith is comprised of several stepped planation surfaces (Wirthmann, 1966, 1970); the oldest surface being the most elevated (Trescases, 1975; Latham, 1986). Each step of surface development was related to repeated uplift phases and/or sea level changes (Chardon and Chevillotte, 2006; Chevillotte et al., 2006).

Paleomagnetic dating methods have been successfully applied to date ferricrust development over obducted peridotites. This method involves a comparison of remanent magnetisation preserved in $\mathrm{Fe}$ oxides to the apparent polar wandering curve of Australia, assuming that Australia and New Caledonia have been rigidly fixed since the Early Oligocene. Preliminary results reveal that a phase of ferric crust development probably ended at c. $25 \pm 5 \mathrm{Ma}$ (Late Oligocene); the associated weathering surface is located on the Tiebaghi Massif (near Koumac; Figure 5), one of the northern klippes of the W coast. This surface has been deeply eroded and dissected; whilst in the rest of the island and especially in the southern lowlands and endorheic basins, weathering continued until Recent time (Sevin et al., 2011).

\section{Early Miocene coastal deposits and vigorous uplift}

Miocene sediments crop out in cliffs of the Mueo and Pindaï peninsulas and islets of the Nepoui Bay (Coudray, 1976; Figure 5); these are the only known Miocene marine sediments of this age in New Caledonia. The Nepoui series consists of two subunits, the lower unit, the base of which does not crop out, consists of lagoonal limestone and calcareous sands that contain Aquitanian (Early Miocene) foraminifers (Maurizot, unpublished data, 2011). The upper unit, c. $100 \mathrm{~m}$ thick, has an erosive lower boundary and starts with slightly unconformable torrential cobble conglomerate, c. 100m thick, overlain by reddish to yellow calcareous sands with conglomerate lenses, topped by pre-Late Miocene yellow calcareous sands (Coudray, 1976). In the Mueo Peninsula, gently S-dipping conglomerate and coarse sands overlie severely sheared serpentinite, which represents the tectonic sole of the Ophiolitic Nappe, Poya Terrane basalts and the folded Late Eocene Népoui Flysch, with angular unconformity. Well-rounded pebbles are mainly composed of peridotite, minor dolerite and rare amphibole-bearing felsic rocks, which belong to the Early Eocene dyke system of the Peridotite Nappe (Cluzel et al., 2006). The most significant feature of Early Miocene conglomerate is the occurrence of, pebbles and sand-sized particles of ferricrete and silcrete that reflect the erosion of older regolith. The Goa N'doro Formation which crops out on the E coast near Houailou (Figure 5) is formed of two sub-units (Orloff and Gonord, 1968), the younger of which is composed of a conglomerate similar to that of Nepoui.
This conglomerate has been tentatively correlated to the Late Oligocene by Chardon and Chevillotte (2006), but could be a lateral equivalent of the Early Miocene Nepoui conglomerate as well.

The occurrence of Nepoui conglomerate and its possible E coast correlative, and the new time constraints on regolith formation infer that (1) peridotite weathering started soon after obduction (a fact signalled by Coudray, 1976), (2) this stage of regolith development stopped locally at c. $25 \pm 5 \mathrm{Ma}$ and (3) this event may be roughly correlated with the occurrence of Early Miocene dramatic erosion that may be due to either climatic (sea level drop) and/or tectonic (uplift) events.

\section{Neogene-Recent tectonics and morphology of New Caledonia}

Late Oligocene granitoids (Cluzel et al., 2005), Early Miocene sediments (Chardon et al., 2008), and regolith, including resedimented laterite deposits (Cluzel and Vigier, 2008; Chardon and Chevillotte, 2006) are crosscut by fault sets. These tectonic events may be due to Miocene uplift, but time constraints are not always available and additional work is necessary to better constrain this fault set that partly controls the weathering of peridotites (Leguéré, 1976; Elias, 2002), and is therefore of some importance for the nickel resource.

The asymmetrical morphology of the "Grande Terre", which is tilted SW-wards, may be related to distinct events: (1) a Late Oligocene-Early Miocene post-obduction extension (Lagabrielle et al., 2005); (2) a syn- to post-Early Miocene transtension associated with subduction reversal and opening of the North Fiji Basin (Chardon and Chevillotte, 2006); and, (3) the recent involvement of the Australian Plate in the fore-arc bulge of the Vanuatu (New Hebrides) volcanic arc, as revealed by uplift of the Loyalty Islands and by the uplifted fringing reefs located in the SE of the Grande Terre (Dubois et al., 1974).

It is worth noting that the oldest known reefal construction on the margins of Grande Terre is not older than 1.4 Ma (Cabioch et al., 2008); whilst the Present barrier reef and lagoon are not older than $0.4 \mathrm{Ma}$ (Frank et al., 2006) and underwent several periods of emersion during Holocene sea level low stands (Coudray, 1976; Chardon et al., 2008; Cabioch et al., 1999, 2008; Le Roy et al., 2008). During the latter periods, the lagoon was drained and rivers formed canyons across it. The paths of these rivers form submerged meanders that are now clearly visible.

Undated terrestrial deposits referred to as "Fluvio-lacustrine System" fill in paleo-valleys and endorheic weathering cells of the Massif du Sud (Trescases, 1975). Those sediments, 50-100 m thick, with coarse torrential conglomerate at the base, mainly consist of reworked laterite (actually Fe oxide), detrital chromite, and supergene silica clasts. They have been tentatively correlated to the Late Oligocene by Chardon and Chevillote (2006). At present, they are actively and unequally eroded.

\section{Mineral resources of New Caledonia}

In contrast to many islands of the Pacific Rim, New Caledonia has no large volcanogenic ore deposits and only minor polymetallic orebodies of the sedimentary exhalative type are located in Late Cretaceous metasediments (Diahot Terrane). Gold was discovered in 1863 near Pouebo and, later, the Fern Hill mine (near Ouegoa) 
produced $214 \mathrm{~kg}$ of $\mathrm{Au}$ between 1873-1900. Many other Au occurrences have been discovered, but none of them have economic importance. Copper, $\mathrm{Pb}$ and $\mathrm{Ag}$ were discovered and mined in the Diahot Region during the late $19^{\text {th }}$ century but all mines closed in the 1930's. Chromite lenses associated with the Peridotite Nappe have been mined in many places of the Massif du Sud, with that in the Tiebaghi Massif (North) producing 3.3 Mt chromite between 19021976.

However, these resources are now worked out and New Caledonia's mining industry depends upon the Ni contained in weathered peridotites. New Caledonia ranks fifth among the world's nickel ore producers (Elias, 2002); nickel concentration results from the hydrolysis of olivine $(0.4 \% \mathrm{Ni})$ and pyroxene $(0.025 \% \mathrm{Ni})$ by weathering solutions and subsequent concentration as silicate minerals or adsorbed mineral phases in the lower part of the weathering profile. The lateritic profile developed on obducted peridotite in New Caledonia belongs to the hydrous Mg silicate type (Brand et al., 1998; Freyssinet et al., 2005). It is characterized by an absolute enrichment or concentration of $\mathrm{Ni}$ in the saprolite zone, which consists of secondary serpentine, neoformed goethite, smectitic clays and garnierite. Much of the nickel is re-precipitated within the saprolite by substituting $\mathrm{Ni}$ for $\mathrm{Mg}$ in secondary serpentines (which can contain up to $5 \% \mathrm{Ni}$ ) and in garnierite, which can grade over $20 \% \mathrm{Ni}$ (Pelletier, 1996). This silicate (or garnieritic) ore has been actively mined since the late $19^{\text {th }}$ century but reserves are rapidly being depleted. Lesser Ni concentrations are found in oxidised (lateritic) ore $(1.0-1.5 \% \mathrm{Ni})$; however, reserves are enormous and lower grade lateritic ore will represent the bulk of $\mathrm{Ni}$ reserves of New Caledonia in the future.

\section{Summary and conclusions}

During Permian-Early Cretaceous time, New Caledonia had almost continuous volcaniclastic sedimentation. Its location at the eastern edge of a marginal basin system is consistent with discontinuous connections with continental sources of sediments; in
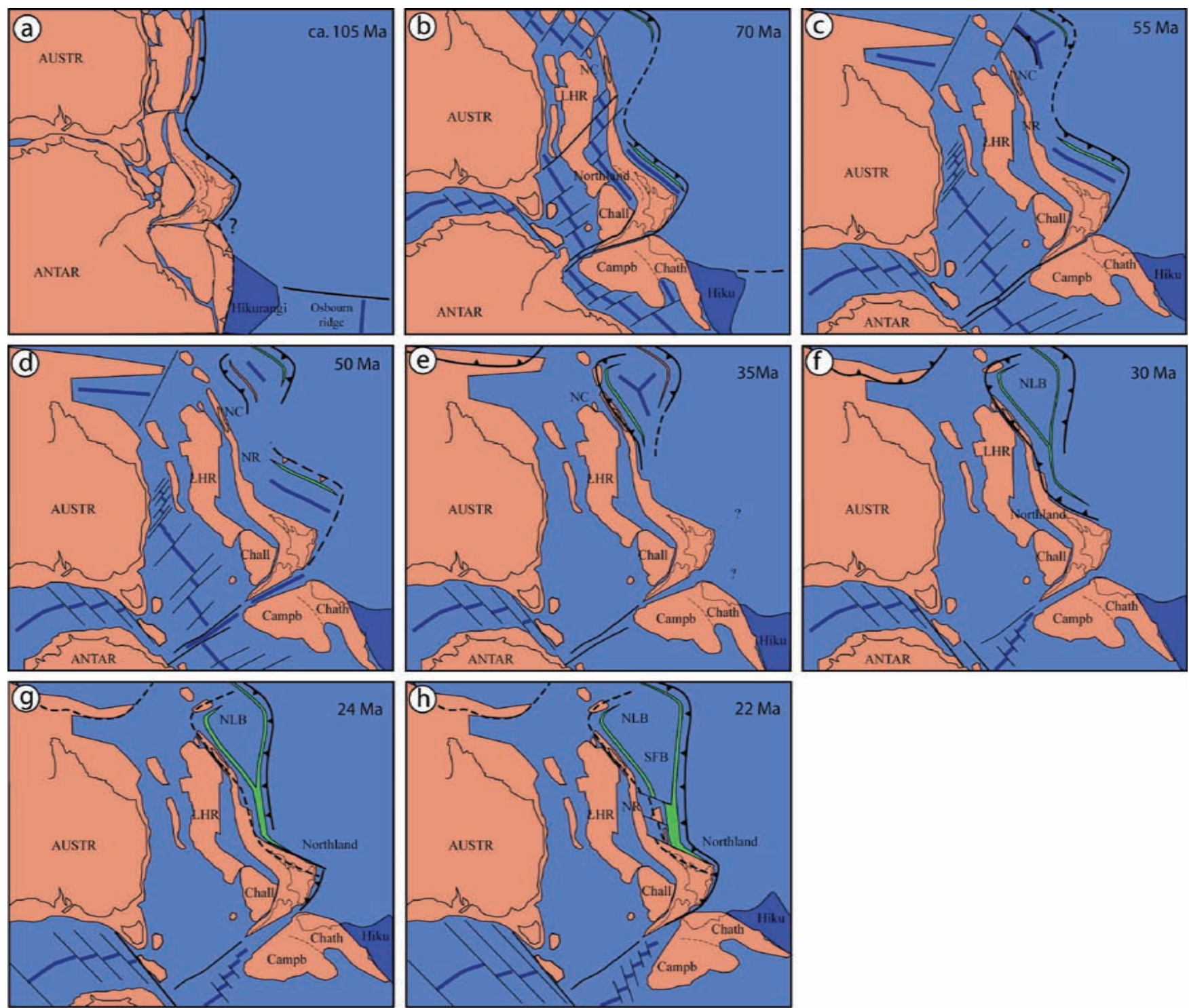

Figure 11 Summary of the Late Cretaceous-Miocene paleogeographic evolution of the SW Pacific (after Gaina et al., 1998; Cluzel et al., 1999; Hall, 2002; Sdrolias et al., 2003; Crawford et al., 2003). Campb: Campbell Plateau; Chall: Challenger Plateau; Chatham Rise; Hiku: Hikurangi Plateau; LHR: Lord Howe Rise; NC: New Caledonia; NLB: North Loyalty Basin; NR: Norfolk Ridge; SFB: South Fiji Basin. 
contrast, long periods of isolation are responsible for prominent endemism.

During the Late Cretaceous, the Australian margin was the site of marginal break-off and marginal basin opening; it is worth noting that all marginal basins opened almost synchronously; and that no Late Cretaceous volcanic-arc is hitherto known, therefore, it may be suggested that the eastward flow of the upper asthenosphere triggered by rapidly stretching lithosphere prevented a "normal" mantle wedge to form (Cluzel et al., 2011). At the end of the Paleocene, a new NEdipping subduction zone appeared at or close to the spreading ridge of the South Loyalty Basin (Figures 10 and 11c). During the Paleocene and Eocene, back-arc spreading of the North Loyalty Basin induced the roll-back and SE-ward migration of the Loyalty arc-trench system (Figure 11d). The trench reached the northern tip of the Norfolk Ridge in the Early Eocene and continental subduction/obduction started (Figure 11e); new subduction along the $\mathrm{W}$ coast relayed the Loyalty arc-trench system subduction blocked by the Norfolk Ridge (Figure 11f), this short-lived subduction was finally blocked by the Lord Howe Rise. The Eocene jamming of subduction and actively spreading North Loyalty and South Fiji basins provoked the activation (or reactivation) of the Tonga subduction; meanwhile, the system propagated southwards and reached the eastern Lord Howe Rise and northern New Zealand in Oligocene (Figure 11f) and Miocene times (Figure 11g) respectively. During the Miocene, the Tonga subduction was active and complex back-arc basins opened until it reached its present location and was eventually blocked by the collision of the Australian Plate with South Island and Hikurangi Plateau.

The pre-Oligocene geology of New Caledonia within the framework of SW Pacific evolution provides a good example of preserved pre-collision stages because no crustal thickening happened after the development of foreland basins, HP-LT complexes, melanges, obduction etc. It may be prominently useful to elucidate the more complex evolution of many accretionary orogens such as those of Paleozoic Central Asia.

During Oligocene-Recent time, New Caledonia emerged and underwent several phases of weathering that formed thick regolith, some of which is of major economic importance. The predominance of peridotite during the early stages of resettling by vegetation probably resulted in the unique endemic flora, which is at present located in ultramafic massifs.

\section{Acknowledgements}

The authors are greatly indebted to Hamish Campbell and Dominique Chardon for extensive reviewing and improvements of an early draft of this article.

\section{References}

Adams, C.J., Cluzel, D. and Griffin, W.L., 2009, Detrital zircon ages and provenance of sedimentary rocks in basement Mesozoic terranes of New Caledonia: Australian Journal of Earth Sciences, v. 56, pp. 1023-1047.

Aitchison, J.C., Clarke G.L., Cluzel D. and Meffre, S., 1995a, Eocene arccontinent collision in New Caledonia and implications for regional southwest Pacific tectonic evolution: Geology, v. 23, pp. 161-164.

Aitchison, J.C., Meffre, S. and Cluzel, D., 1995b, Cretaceous/Tertiary radiolarians from New Caledonia: Geological Society of New Zealand, Miscellaneous Publication 81A, 70 pp.

Aitchison, J.C., Ireland T.R., Clarke G.L., Cluzel D. and Meffre S., 1998, U/ $\mathrm{Pb}$ SHRIMP age constraints on the tectonic evolution of New Caledonia and regional implications: Tectonophysics, v. 299, pp. 333-343.
Ali, J.R. and Aitchison, J.C., 2000, Significance of palaeomagnetic data from the oceanic Poya Terrane, New Caledonia, for SW Pacific tectonic model: Earth and Planetary Science Letters, v. 177, pp. 153-161.

Andrews, J.E. and Packham, G.H. et al., 1975, Initial reports of the Deep Sea Drilling Project, Volume 30: U.S. Government Printing Office, Washington D.C. 753 pp.

Aronson, J.L. and Tilton, G.R., 1971, Probable Precambrian detrital zircons in New Caledonia and Southwest Pacific continental structure: Geological Society of America, Bulletin 82, pp. 3449-3456.

Auzende, J.-M., van de Beuque, S., Regnier, M., Lafoy, Y. and Symonds, P., 2000, Origin of the New Caledonian ophiolites based on a FrenchAustralian seismic transect: Marine Geology, v. 162, pp. 225-236.

Avias, J., 1967, Overthrust structure of the main ultrabasic New Caledonian massifs: Tectonophysics, v. 4, pp. 531-541.

Baldwin, S.L., Rawlings, T. and Fitzgerald, P.G., 2007, Thermochronology of the New Caledonian high-pressure terrane: implications for middle Tertiary plate boundary processes in the Southwest Pacific: Geological Society of America, Special Paper 419, pp. 117-134, doi: 10.1130/ 2006.2419(06).

Ballance, P.F. and Campbell, J.D., 1993, The Murihiku arc-related basin of New Zealand (Triassic-Jurassic), in Ballance P. F. (ed), South Pacific sedimentary basins, Sedimentary Basins of the World 2: Elsevier, Amsterdam, pp. 21-33.

Baubron, J.C., Guillon, J.H. and Récy, J., 1976, Géochronologie par la méthode K/Ar du substrat volcanique de l'île de Maré, archipel des Loyauté (SudOuest Pacifique): Bureau de Recherches Géologiques et Minières, Bulletin 4, pp. 165-176.

Bitoun, G. and Récy, J., 1982, Origine et évolution du bassin des Loyauté et de ses bordures après la mise en place de la série ophiolitique de NouvelleCalédonie: Contribution à l'étude géodynamique du sud-ouest Pacifique: Travaux et documents ORSTOM, Paris. pp. 505-539.

Blake, M.C. Jr., Brothers, R.N. and Lanphere, M.A., 1977, Radiometric ages of blueschists in New Caledonia, in International Symposium on Geodynamics of the South-West Pacific, Nouméa, 1976: Technip ed., pp. 279-282.

Bogdanov, I., Huaman, D., Thovert, J.F., Genthon, P. and Adler, P., 2011, Tectonic stresses seaward of an aseismic ridge-trench collision zone. A remote sensing approach on the Loyalty Islands, SW Pacific: Tectonophysics, v. 499, pp. 77-91, doi:10.1016/j.tecto.2010.12.007

Brand, N.W., Butt, C.R.M., and Elias, M., 1998, Nickel laterites: Classification and features: AGSO Journal of Australian Geology and Geophysics, v. 17 , pp. $81-88$

Bryan, S.E., Constantine, A.E., Stephens, C.J., Ewart, A., Schon, R.W. and Parianos, J., 1997, Early Cretaceous volcano-sedimentary successions along the eastern Australian continental margin: implications for the break-up of eastern Gondwana: Earth and Planetary Science Letters, v. 153 , pp. $85-102$.

Cabioch, G., Correge, T., Turpin, L., Castellaro, C. and Récy, J., 1999, Development patterns of fringing and barrier reefs in New Caledonia (southwest Pacific): Oceanologica Acta, v. 22, pp. 567-578.

Cabioch, G., Montaggioni, L., Thouveny, N., Frank, N., Sato, T., Chazottes, V., Dalamasso, H., Payri, C., Pichon, M. and Semah, A.M., 2008, The chronology and structure of the western New Caledonian barrier reef tracts: Palaeogeography, Palaeoclimatology, Palaeoecology, doi:10.1016/ j.palaeo.2008.07.014.

Campbell, H.J, 1984, Petrography and metamorphism of the Téremba Group (Permian to Lower Triassic) and the Baie de St. Vincent Group (Upper Triassic to Lower Jurassic), New Caledonia: Journal of the Royal Society of New Zealand, v. 14, pp. 335-348.

Campbell, H.J., Grant-Mackie, J.A. and Paris, J.P., 1985, Geology of the Moindou-Téremba area, New Caledonia. Stratigraphy and structure of the Téremba Group (Permian -Lower Triassic) and Baie de St Vincent Group (Upper Triassic-Lower Jurassic), Géologie de la France, v. 1, pp. 19-36.

Carroué, J.P., 1972, Carte et notice explicative de la carte géologique de la Nouvelle-Calédonie au 1/50 000è, feuille Pouembout. Bureau de Recherches Géologiques et Minières (France).

Carson, C.J., Powell, R. and Clarke, G.L., 1999, Calculated mineral equilibria for eclogites in $\mathrm{CaO}-\mathrm{Na}_{2} \mathrm{O}-\mathrm{FeO}-\mathrm{MgO}-\mathrm{Al}_{2} \mathrm{O}_{3}-\mathrm{SiO}_{2}-\mathrm{H}_{2} \mathrm{O}$; application to the Pouebo Terrane, Pam peninsula, New Caledonia: Journal of Metamorphic Geology, v. 17, pp. 9-24.

Carson, C.J., Clarke, G.L. and Powell, R., 2000, Hydration of eclogite, Pam 
Peninsula, New Caledonia: Journal of Metamorphic Geology, v. 18, pp. 79-90.

Chardon, D. and Chevillotte V., 2006, Morphotectonic evolution of the New Caledonia Ridge (Pacific Southwest) from post-obduction tectonosedimentary record: Tectonophysics, v. 420, pp. 473-491.

Chardon, D., Austin, J.A., Cabioch, G., Pelletier, B., Saustrup, S. and Sage F., 2008, Neogene history of the northeastern New Caledonia continental margin from multichannel reflection seismic profiles: Comptes Rendus Géoscience, v. 340, pp. 68-73.

Chevalier, J.P., 1968, Géomorphologie de l'île de Maré. Les récifs actuels de l'île de Maré. Les Madréporaires fossiles de Maré - Expédition française sur les récifs coralliens de la Nouvelle Calédonie, 1960-1963: Fondation Singer-Polignac Ed., v. 3, pp. 1-57.

Chevillotte, V., Chardon, D., Beauvais, A., Maurizot, P. and Colin F., 2006, Long-term tropical morphogenesis of New Caledonia (Southwest Pacific): Importance of positive epeirogeny and climate change: Geomorphology, v. 81 , pp. $361-375$.

Clarke, G., Aitchison, J.C. and Cluzel, D., 1997, Eclogites and blueschists of the Pam Peninsula, NE New Caledonia: a reappraisal: Journal of Metamorphic Petrology, v. 38, pp. 843-876.

Cluzel, D., 1998. Le "flysch post-obduction" de Népoui, un bassin transporté ? Conséquences sur l'âge et les modalités de l'obduction tertiaire en Nouvelle-Calédonie (Pacifique sud-ouest): Comptes Rendus de l'Académie des Sciences, Paris., v. 327, pp. 419-424.

Cluzel, D. and Meffre S., 2002, L'unité de la Boghen (Nouvelle-Calédonie, Pacifique sud-ouest): un complexe d'accrétion jurassique. Données radiochronologiques préliminaires $\mathrm{U}-\mathrm{Pb}$ sur les zircons détritiques : Comptes Rendus Géosciences, v. 334, pp. 867-874.

Cluzel, D. and Vigier, B., 2008, Syntectonic mobility of supergene nickel ores of New Caledonia (Southwest Pacific). Evidence from faulted regolith and garnierite veins: Resource Geology, v. 58, pp. 161-170.

Cluzel, D., Aitchison, J.C., Clarke, G., Meffre, S. and Picard, C. 1995a, Dénudation tectonique du complexe à noyau métamorphique de haute pression tertiaire (Nord de la Nouvelle-Calédonie, Pacifique, France), Données cinématiques: Comptes Rendus de l'Académie des Sciences, Paris, v. 321, pp. 57-64.

Cluzel, D., Clarke, G. and Aitchison, J.C., 1995b, Northern New Caledonia high-pressure metamorphic core complex. From continental subduction to extensional exhumation: Pacrim'95 Congress, Auckland 11/95, Proceedings Volume, pp. 129-134.

Cluzel, D., Chiron, D. and Courme, M.D., 1998, Discordance de l'Eocène supérieur et événements pré-obduction en Nouvelle-Calédonie (Pacifique sud-ouest): Comptes Rendus de l'Académie des Sciences, Paris, v. 327, pp. 485-491.

Cluzel, D., Aitchison, J.C., Black, P.M. and Picard, C., 1999, Origin and fate of Southwest Pacific marginal basins; an appraisal from New Caledonia, in Baldwin, L. and Lister G.S. (eds), Mid-Cretaceous to recent plate boundary processes in the Southwest Pacific: '99 Penrose Conference, Arthur's Pass, New Zealand, Abstracts Volume, pp. 77-79.

Cluzel, D., Aitchison, J.C. and Picard, C., 2001, Tectonic accretion and underplating of mafic terranes in the Late Eocene intraoceanic fore-arc of New Caledonia (Southwest Pacific). Geodynamic implications: Tectonophysics, v. 340, pp. 23-60.

Cluzel, D., Bosch, D., Paquette, J.L., Lemennicier, Y., Montjoie, Ph. and Ménot, R.P., 2005, Late Oligocene post-obduction granitoids of New Caledonia: a case for reactivated subduction and slab break-off: The Island Arc, v. 14, pp. 254-271.

Cluzel, D., Meffre, S., Maurizot, P. and Crawford, A.J., 2006, Earliest Eocene (53 Ma) convergence in the Southwest Pacific; evidence from preobduction dikes in the ophiolite of New Caledonia: Terra Nova, v. 18, pp. 395-402.

Cluzel, D., Adams, C.J.A., Meffre, S., Campbell, H. and Maurizot, P., 2010, Discovery of Early Cretaceous rocks in New Caledonia (Southwest Pacific). New geochemical and U-Pb zircon age constraints on the transition from subduction to marginal breakup: The Journal of Geology, v. 118, pp. 381-397.

Cluzel, D., Adams, C.J., Maurizot, P. and Meffre, S., 2011, Detrital zircon records of Late Cretaceous syn-rift sedimentary sequences of New Caledonia: an Australian provenance questioned: Tectonophysics, v. 501, pp. 17-27, doi: 10.1016/j.tecto.2011.01.007

Cluzel, D., Jourdan, F., Meffre, S., Maurizot, P. and Lesimple, S., 2012, Earliest Eocene MORB-like amphibolites from the sole of the ophiolite of New
Caledonia; ${ }^{40} \mathrm{Ar}^{39}{ }^{39} \mathrm{Ar}$, U-Pb, and geochemical evidence for subduction inception at a spreading ridge: Tectonics (in press).

Collot, J.Y., Malahoff, A., Récy, J., Latham, G. and Missegue, F., 1987, Overthrust emplacement of New Caledonia ophiolite: geophysical evidence: Tectonics, v. 6, pp. 215-232

Collot, J., Géli, L., Lafoy, Y., Vially, R., Cluzel, D., Klingelhoefer, D. and Nouzé, H, 2008, Tectonic history of northern New Caledonia Basin from deep offshore seismic reflection: relation to Late Eocene obduction in New Caledonia, Southwest Pacific: Tectonics, v. 27, (TC6006), doi: $10.1029 / 2008$ TC02263.

Coudray, J., 1976, Recherches sur le Néogène et le Quaternaire marins de la Nouvelle-Calédonie; contribution de l'étude sédimentologique à la connaissance de l'histoire Géologique post-éocène, in Expédition française sur les récifs coralliens de la Nouvelle-Calédonie; volume Huitième. 5-275: Thèse Doct. d'Etat, Montpellier.

Crawford, A. J., Meffre, S. and Symonds, P.A., 2003, 120 to 0 Ma tectonic evolution of the Southwest Pacific and analogous geological evolution of the 600 to 220 Ma Tasman Fold Belt System: Geological Society of Australia, Special Publication 22, pp. 377-397.

Dubois, J., Launay, J. and Récy, J., 1974, Uplift movements in New CaledoniaLoyalty Islands area and their plate tectonics interpretation: Tectonophysics, v. 24, pp. 133-150.

Dubois, J., Deplus, C., Diament, M., Danie, J. and Collot, J.Y., 1988 Subduction of the Bougainville seamount (Vanuatu); mechanical and geodynamic implications: Tectonophysics, v. 149, pp. 111-119.

Eissen, J.P., Crawford, A.J., Cotten, J., Meffre, S., Bellon, H., Delaune, M., 1998, Geochemistry and tectonic significance of basalts in the Poya Terrane, New Caledonia: Tectonophysics, v. 284, pp. 203-219.

Elias, M., 2002, Nickel laterite deposits: Geological overview, resources and exploitation, in Cooke, D. R. and Pongratz, J. (eds), Giant ore deposits: characteristics, genesis and exploration: CODES Special Publication 4. Centre for Ore Deposit Research, University of Tasmania, Hobart, pp. 205-220.

Fitzherbert, J.A., Clarke, G.L. and Powell, R., 2003, Lawsonite-omphacitebearing metabasites of the Pam Peninsula, NE New Caledonia: evidence for disrupted blueschist- to eclogite-facies conditions: Journal of Petrology, v. 44, pp. 1805-1831.

Fitzherbert, J.A., Clarke, G.L. and Powell, R., 2005, Preferential retrogression of high-P metasediments and the preservation of blueschist to eclogite facies metabasite during exhumation, Diahot terrane, NE New Caledonia: Lithos, v. 83, pp. 67-96.

Fleming, C.A., 1969, The Mesozoic of New Zealand: Chapters in the history of the Circum-Pacific Mobile Belt: Quarterly Journal of the Geological Society, v. 125 , pp. 125-170, doi: 10.1144/?gsjgs.125.1.0125

Frank, N., Turpin, L., Cabioch, G., Blamart, D., Tressens-Fedou, M., Colin, C., Jean-Baptiste, P., 2006, Open system U-series ages of corals from a subsiding reef in New Caledonia: Implications for sea level changes, and subsidence rate: Earth and Planetary Science Letters, v. 249, pp. 274-289.

Freyssinet, P., Butt, C.R.M., Morris, R.C., and Piantone P., 2005, Ore-forming processes related to lateritic weathering: Economic Geology 100th Anniversary Volume, Society of Economic Geologists, Inc., pp. 681722.

Gaina, C., Müller, D.R., Royer, J.Y., Stock, J., Hardebeck, J. and Symonds, P., 1998, The tectonic history of the Tasman Sea: a puzzle with 13 pieces: Journal of Geophysical Research, v. 103, pp. 12,413-12,433, doi:10.1029/ 98JB00386.

Ghent, E.D., Roddick, J.C. and Black, P.M., 1994, ${ }^{40} \mathrm{Ar} /{ }^{39} \mathrm{Ar}$ dating of white micas from the epidote to the omphacite zones, northern New Caledonia; tectonic implications: Canadian Journal of Earth Sciences, v. 31, pp. $995-1001$

Grant-Mackie, J.A., Paris, J.P., Freneix, S. and Campbell, J.D., 1977, Advances in correlation of Mesozoic sequences in New Zealand and New Caledonia: 25th International Geological Congress, Abstracts Volume 1, pp. 268269.

Greene, H.G., Collot, J.-Y., Fischer, M.A. and Crawford, A.J., 1994, Neogene tectonic evolution of the Hebrides Island arc: a review incorporating ODP drilling results. Proceedings of the Ocean Drilling Program. Scientific results, Leg 134. pp.19-46.

Guérangé, B., Lille, R. and Lozes, J., 1975, Etude géologique des terrains anté-oligocènes de la chaîne centrale néo-calédonienne: stratigraphie, régime de sédimentation, évolution structurale et métamorphisme: 
Bulletin du Bureau de Recherches Géologiques et Minières, France. sect. 4, 2, pp. 121-137.

Guillon, J.-H. and Gonord, H., 1972, Premières données radiométriques concernant les basaltes de Nouvelle-Calédonie. Leurs relations avec les grands événements de l'histoire géologique de l'arc mélanésien interne au Cénozoïque : Comptes Rendus de l'Académie des Sciences, Paris, Ser. D., v. 275, pp. 309-312.

Gutscher, M.A., Kukowski, N., Malavieille, J. and Lallemand, S., 1998, Episodic imbricate thrusting and underthrusting: Analog experiments and mechanical analysis applied to the Alaskan Accretionary Wedge: Journal of Geophysical Research, v. 103, B5, pp. 10,161-10,176, doi:10.1029/97JB03541

Hall, R., 2002, Cenozoic geological and plate tectonic evolution of SE Asia and the SW Pacific: computer-based reconstructions, model and animations: Journal of Asian Earth Sciences, v. 20, pp. 353-431.

Hayes, D. E. and Ringis, J., 1973, Seafloor spreading in the Tasman Sea: Nature, v. 244, pp. 454-458.

Klingelhoefer F., Lafoy Y., Collot J., Cosquer E., Géli L., Nouzé H., Vially R., 2007, Crustal structure of the basin and ridge system west of New Caledonia (southwest Pacific) from wide-angle and reflection seismic data: Journal of Geophysical Research, v. 112, B11102, doi:10.1029/ 2007JB005093.

Kroenke, L.W. and Eade, J.V., 1982, Geomorphology, Structure and Geochemistry of North Fiji Basin Triple Junction: AAPG Bulletin, v. 66, p. 974.

Lafoy, Y., Missègue F., Cluzel, D. and Le Suavé, R., 1996, The Loyalty-New Hebrides Arc collision: effects on the Loyalty ridge and basin system, SW Pacific (First results of the ZoNéCo Programme: Marine Geophysical Research, v. 18, pp. 337-356.

Lagabrielle, Y., Maurizot, P., Lafoy, Y., Cabioch, G., Pelletier, B., Régnier, M., Wabete, I. and Calmant, S., 2005, Post-Eocene extensional tectonics in Southern New Caledonia (SW Pacific): Insights from onshore fault analysis and offshore seismic data: Tectonophysics, v. 403, pp. 1-28.

Latham, M., 1986, Altération et pédogenèse sur roches ultrabasiques en Nouvelle-Calédonie : genèse et évolution des accumulations de fer et de silice en relation avec la formation du modelé: Thesis Science, Dijon, $331 \mathrm{pp}$.

Leguéré, J., 1976, Des corrélations entre la tectonique cassante et l'altération supergène des péridotites de Nouvelle Calédonie: $\mathrm{PhD}$ thesis, University of Montpellier, France, 95 pp.

Le Roy, P., Cabioch, G., Monod, B., Lagabrielle, Y., Pelletier, B. and Flamand, B., 2008, Late Quaternary history of the Nouméa lagoon (New Caledonia, South West Pacific) as depicted by seismic stratigraphy and multibeam bathymetry: A modern model of tropical rimmed shelf: Palaeogeography, Palaeoclimatology, Palaeoecology, v. 270, pp. 29-45.

Maillet, P., Monzier, M., Selo, M. and Storzer, D., 1983, The D’Entrecasteaux Zone (Southwest Pacific); a petrological and geochronological reappraisal: Marine Geology, v. 53, pp. 179-197.

Marchesi, C., Garrido, C.J., Godard, M., Belley, F. and Ferré, E., 2009, Migration and accumulation of ultra-depleted subduction-related melts in the Massif du Sud ophiolite (New Caledonia): Chemical Geology, v. 266 , pp. $171-186$.

Maurizot, P., 2011, Premiers enregistrements sédimentaires de la convergence pré-obduction en Nouvelle-Calédonie : Formation d'un complexe d'accrétion à l'Eocène inférieur dans le Nord de la Grande-Terre et mise en place de la nappe des Montagnes Blanches. Bulletin de la Société Géologique de France (in press).

Maurizot, P. and Lafoy, Y., 2003, Notice explicative, Carte géol. NouvelleCalédonie (1/50 000), feuille Maré, Îles Loyauté. Nouméa: Service des Mines et de l'Energie, Bureau de Recherches Géologiques et Minières. Carte géologique par Maurizot, P. et al., 2003.

Maurizot, P. and Vendé-Leclerc, M., 2009, New Caledonia geological map, scale 1/500,000: Direction de l'Industrie, des Mines et de l'Energie Service de la Géologie de Nouvelle-Calédonie, Bureau de Recherches Géologiques et Minières, Notice explicative par Maurizot, P. et Collot, J., 2009.

Maurizot, P., Tessarolo, C. and Feigner, D., 1985, Carte géologique Territoires d'Outre-Mer, Nouvelle-Calédonie (1/50000), feuille Touho-Poindimié: Bureau de Recherches Géologiques et Minières, Notice explicative par Maurizot, P., Tessarolo, C. et Feigner, D., 81 pp.

Maurizot P., Eberlé J.M., Habault C. and Tessarolo C., 1989, Carte géol. Territoires d'Outre-Mer, Nouvelle-Calédonie (1/50 000), feuille Pam-
Ouégoa, 2e édition, Bureau de Recherches Géologiques et Minières, Notice explicative par Maurizot, P., Eberlé, J.M., Habault, C. et Tessarolo, C., $81 \mathrm{pp}$.

Mc Dougall, I. and Van Der Lingen, G.J., 1974, Age of the rhyolites of the Lord Howe Rise and the evolution of the southwest Pacific Ocean: Earth and Planetary Science Letters, v. 21, pp. 117-126, doi:10.1016/0012$821 X(74) 90044-2$

Meffre, S., 1995, The development of arc-related ophiolites and sedimentary sequences in New Caledonia: PhD thesis, University of Sydney (unpublished), $236 \mathrm{pp}$.

Meffre, S., Aitchison, J.C. and Crawford, A. J., 1996, Geochemical stratigraphy of boninites and tholeiites from the Permo-Triassic Koh Ophiolite, New Caledonia: Tectonics, v. 15 , pp. 67-83.

Nicholson, K.N., Picard, C. and Black, P.M., 2000, A comparative study of Late Cretaceous ophiolitic basalts from New Zealand and New Caledonia: implications for the tectonic evolution of the SW Pacific: Tectonophysics, v. 327 , pp. $157-171$.

Nicholson, K.N., Maurizot, P., Black, P.M., Picard, C., Simonetti, A., Stewart, A. and Alexander, A., 2011, Geochemistry and age of the Nouméa Basin lavas, New Caledonia: Evidence for Cretaceous subduction beneath the eastern Gondwana margin: Lithos, v. 125, pp. 659-674, doi:10.1016/ j.lithos.2011.03.018

Orloff, O. and Gonord, H., 1968, Note préliminaire sur un nouveau complexe sédimentaire continental situé sur les massifs du Goa N'Doro et de Kadjitra (région cotières à l'est de la Nouvelle-Calédonie), définition de la formation et conséquences de cette découverte sur l'âge des fractures: Comptes Rendus Hebdomadaires des Séances de l'Académie des Sciences, Série D: Sciences Naturelles, v. 267, pp. 5-8.

Paquette, J.L. and Cluzel, D., 2007, U-Pb zircon dating of post-obduction volcanic-arc granitoids and a granulite-facies xenolith from New Caledonia. Inference on Southwest Pacific geodynamic models: International Journal of Earth Sciences (Geologische Rundschau) v. 96, pp. 613-622, doi : 10.1007/s00531-006-0127-1

Paris, J.P., 1981, Géologie de la Nouvelle-Calédonie. Un essai de synthèse: Bureau de Recherches Géologiques et Minières, Memoirs, v. 113, $278 \mathrm{pp}$.

Pelletier, B., 1996, Serpentine in nickel silicate ore from New Caledonia, in Grimsey, E.J. and Neuss, I. (eds), Nickel '96: mineral to market. The Australasian Institute of Mining and Metallurgy, Publication Series 6/ 96, pp. 197-205.

Pontoise, B., Collot, J.Y., Missegue, F. and Latham, G., 1982, Sismique réfraction dans le bassin des Loyauté: Résultats et discussion, in Equipe de Géologie-Géophysique du Centre ORSTOM de Nouméa: Contribution à l'étude géodynamique du Sud-Ouest Pacifique. Travaux et Documents ORSTOM, 147 , pp. $541-548$

Prinzhoffer, A., 1981, Structure et pétrologie d'un cortège ophiolitique: le massif du Sud (Nouvelle-Calédonie): Thèse Ing.-Doct, E.N.S.M. Paris (unpublished).

Prinzhoffer, A., 1987, Processus de fusion dans les zones d'extension océaniques et continentales, Thèse de doctorat d'Etat (SciD thesis), Université Paris VII, 237 pp.

Prinzhofer, A., Nicolas, A., Cassard, D., Moutte, J., Leblanc, M., Paris, J.P. and Rabinovitch, M., 1980, Structures in the New Caledonia peridotitesgabbros; implications for oceanic mantle and crust: Tectonophysics, v. 69 , pp. $85-112$.

Rawlings, T.J. and Lister, G.S., 1999, Oscillating modes of orogeny in the Southwest Pacific and the tectonic evolution of New Caledonia. Geological Society, London, Special Publication 154, pp. 109-127, doi: 10.1144/?GSL.SP.1999.154.01.05

Rawlings, T.J. and Lister, G.S., 2002, Large scale structure of the eclogiteblueschist belt of New Caledonia: Journal of Structural Geology, v. 24, pp. 1239-1258, doi:10.1016/S0191-8141(01)00128-6

Rigolot, P., 1988, Prolongement méridional des grandes structures de Nouvelle-Calédonie et découverte de monts sous-marins interprétés comme un jalon dans un alignement de hot spot: Comptes Rendus de l'Académie des Sciences, Paris, Ser. 2, v. 307, pp. 965-972.

Schellart, W.P., Lister, G.S. and Toy, V.G., 2006, A Late Cretaceous and Cenozoic reconstruction of the Southwest Pacific region: Tectonics controlled by subduction and slab rollback processes: Earth Science Reviews, v. 76, pp. 191-233.

Sdrolias, M., Müller, R.D. and Gaina, C., 2003, Tectonic evolution of the Southwest Pacific using constraints from back-arc basins: Geological 
Society of Australia, Special Publication 22/Geological Society of America, Special Paper 372, pp. 343-359.

Sevin, B., Ricordel-Prognon, C., Quesnel, F., Cluzel, D., Lesimple, S. and Maurizot, P., 2011, First paleomagnetic dating of ferricrete in New Caledonia: new insight on the morphogenesis and paleoweathering of 'Grande Terre': Terra Nova (in press).

Shor, G.G., Kirk, H.K. and Menard, H.W., 1971, Crustal structure of the Melanesian area: Journal of Geophysical Research, v. 76, pp. 2562-2586.

Smith, W.H.F. and Sandwell, D.T., 1997, Global sea floor topography from satellite altimetry and ship depth soundings: Science, v. 277, pp. 19561962.

Spandler, C., Rubatto, D. and Hermann, J., 2005, Late Cretaceous-Tertiary tectonics of the southwest Pacific: Insights from U-Pb sensitive, highresolution ion microprobe (SHRIMP) dating of eclogite facies rocks from New Caledonia: Tectonics, v. 24, TC3003, doi:10.1029/2004TC001709 Sutherland, R., Collot, J., Lafoy, Y., Logan, G.A., Hackney, R., Stagpoole, V., Uruski, C., Hashimoto, T., Higgins, K., Herzer, R.H., Wood, R. and Mortimer, N., 2010, Lithosphere delamination with foundering of lower crust and mantle caused permanent subsidence of New Caledonia Trough and transient uplift of Lord Howe Rise during Eocene and Oligocene initiation of Tonga-Kermadec subduction, western Pacific. Tectonics, v. 29, TC2004, doi: 10.1029/2099TC002476.

Symonds, P., Auzende, J.M., Lafoy, Y., Van de Beuque, S., Bernardel, G., Stagg, H., 1999. A deep seismic transect from the eastern Australian margin to the New Hebrides arc: the FAUST (French Australian Seismic Transect) program, in Baldwin, L. and Lister, G.S. (eds), Penrose Conference, Mid-Cretaceous to recent plate boundary processes in the Southwest Pacific: Abstract Volume, pp. 91-93.

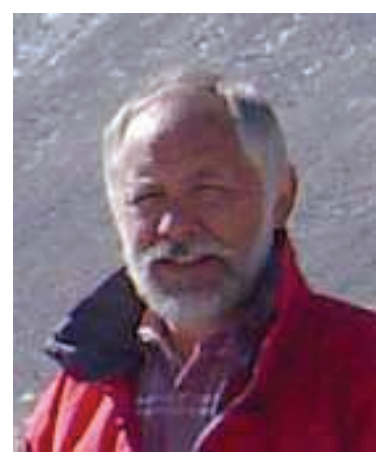

Dominique Cluzel is Professor of Geology at the University of New Caledonia. He was awarded a PhD (Structural Geology) in 1977 at the University Paris XI. In 1990, he was awarded a SciD degree in Geology and Geodynamics: Tectonics and geodynamics of the Okcheon Belt (South Korea). He currently focuses his research interests on the tectonic and geodynamic evolution of New Caledonia and Paleozoic Northwest China, using a multidisciplinary approach.

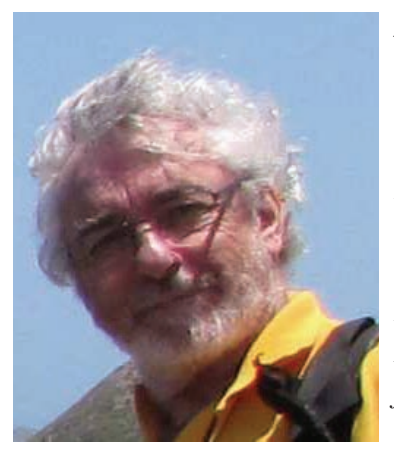

Pierre Maurizot is a senior field geologist with more than thirty years of experience in New Caledonia and adjacent countries of the SW Pacific. $\mathrm{He}$ is presently adviser in the Geological Survey of New Caledonia and director of the Bureau de Recherches Geologiques et Minieres, New Caledonia Branch. He mainly focuses on the sedimentology, stratigraphy and geodynamic setting of Paleogene sediments and allochtonous units of the Grande Terre of New Caledonia.
Trescases, J.-J., 1975, L'evolution géochimique supergène des roches ultrabasiques en zone tropicale : formation des gisements nickélifères de Nouvelle-Calédonie: Memoires ORSTOM Paris, France, v. 78, 259 pp.

Ulrich, M., Picard, C., Guillot, S., Chauvel, C., Cluzel, D. and Meffre, S., 2010, Multiple melting stages and refertilisation process as indicators for ridge to subduction formation: the New Caledonia Ophiolite: Lithos, v. 115 , pp. 223-236.

Van de Beuque, S., 1999, Evolution géologique du domaine péri-calédonien (Sud-ouest Pacifique): PhD thesis, Université de Bretagne Occidentale, Brest, France (unpublished), 270 pp.

Whattam, S.A., 2009, Arc-continent collisional orogenesis in the SW Pacific and the nature, source and correlation of emplaced ophiolitic nappe components: Lithos, v. 113, pp. 88-114, doi:10.1016/j.lithos.2008.11. 009

Whattam, S.A., Malpas, J., Ali, J.R. and Smith, I.E.M., 2008, New SW Pacific tectonic model: Cyclical intraoceanic magmatic arc construction and nearcoeval emplacement along the Australia-Pacific margin in the Cenozoic: Geochemistry Geophysics Geosystems, v. 9, Q03021, doi:10.1029/ 2007GC001710.

Wirthmann, A., 1966, Die reliefentwicklung von Neukaledonien: Deutscher Tagungsber u. Wiesenschaftliche Abhandlung des Dr. Geographen-Tages Boschum 1965, Wiesbaden, pp. 323-325.

Wirthmann, A., 1970, Zur geomorphologie der peridotite auf Neukadedonien: Festschrift H. Wilhelmi, Tübingen Geographische Studien, v. 34, pp. 191-201.

Zachos, J., Pagani, M., Sloan, L., Thomas, E. and Billups, K., 2001, Trends, rhythms, and aberrations in global climate $65 \mathrm{Ma}$ to Present: Science, v. 292 , pp. $686-693$.

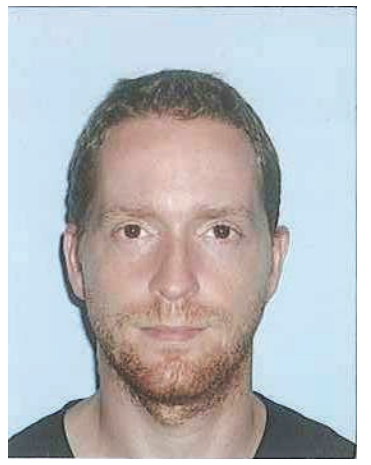

Brice Sevin has a Canadian-French Masters Degree in Metallogeny and Gitology in 2005. He worked for 18 months at the Bureau de Recherches Géologiques et Minières (BRGM). During that time, he produced with his colleagues one 1/50,000 geological map and its explanatory notice. In 2007, he joined the Geological Survey of New Caledonia (SGNC). Initially, he worked in geological mapping and environmental asbestos problems. He has specialized in the study of regolith and supergene nickel deposits - the subject of his PhD thesis.

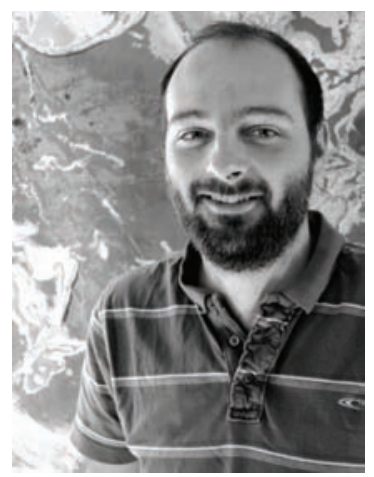

Julien Collot obtained his geophysics engineering diploma from EOST in 2005 and his PhD in 2009 from the Université Européenne de Bretagne (ex-UBO, Brest France). He is currently in charge of marine geophysics at the Geological Survey of New Caledonia. His main research interests are: tectonics and geodynamics of the Southwest Pacific; basin formation, margin fragmentation and subduction dynamics; seismic stratigraphy; subduction initiation processes; and petroleum prospectivity of the SW Pacific. 